\title{
Off-pump versus on-pump coronary artery bypass grafting: A systematic review and meta-analysis of propensity score analyses
}

\author{
Oliver Kuss, $\mathrm{PhD},{ }^{\mathrm{a}}$ Benita von Salviati, $\mathrm{MS},{ }^{\mathrm{a}}$ and Jochen Börgermann, $\mathrm{MD}^{\mathrm{b}}$
}

Objective: Despite numerous randomized and nonrandomized trials on off- and on-pump coronary artery bypass grafting, it remains open which method is superior. Patient selection and small sample sizes limit the evidence from randomized trials; lack of randomization limits the evidence from nonrandomized trials. Propensity score analyses are expected to improve on at least some of these problems. We aimed to systematically review all propensity score analyses comparing off- and on-pump coronary artery bypass grafting.

Methods: Propensity score analyses comparing off- and on-pump surgery were identified from 8 bibliographic databases, citation tracking, and a free web search. Two independent reviewers abstracted data on 11 binary shortterm outcomes.

Results: A total of 35 of 58 initially retrieved propensity score analyses were included, accounting for a total of 123,137 patients. The estimated overall odds ratio was less than 1 for all outcomes, favoring off-pump surgery. This benefit was statistically significant for mortality (odds ratio, $0.69 ; 95 \%$ confidence interval, $0.60-0.75$ ), stroke, renal failure, red blood cell transfusion $(P<.0001)$, wound infection $(P<.001)$, prolonged ventilation $(P<.01)$, inotropic support $(P=.02)$, and intraaortic balloon pump support $(P=.05)$. The odds ratios for myocardial infarction, atrial fibrillation, and reoperation for bleeding were not significant.

Conclusions: Our systematic review and meta-analysis of propensity score analyses finds off-pump surgery superior to on-pump surgery in all of the assessed short-term outcomes. This advantage was statistically significant and clinically relevant for most outcomes, especially for mortality, the most valid criterion. These results agree with previous systematic reviews of randomized and nonrandomized trials. (J Thorac Cardiovasc Surg 2010;140:829-35)

\section{Supplemental material is available online.}

Coronary artery disease is still the most frequent cause of death in industrialized countries. In middle-aged cohorts, coronary artery disease has a prevalence of approximately $20 \%$. More than 50,000 patients undergo coronary artery bypass grafting (CABG) in Germany annually. There is a trend to higher patient age and an increasing prevalence of comorbidities. ${ }^{1}$ Today's surgical standard involves coronary revascularization with heart-lung machine support and

\footnotetext{
From the Institute of Medical Epidemiology, ${ }^{\text {a }}$ Biostatistics, and Informatics, Faculty of Medicine, University of Halle-Wittenberg, Halle (Saale), Germany; and Heart and Diabetes Center North Rhine-Westphalia, ${ }^{\mathrm{b}}$ Department of Thoracic and Cardiovascular Surgery, Ruhr-University Bochum, Bad Oeynhausen, Germany.

Disclosures: Jochen Börgermann (as the principal investigator) and Oliver Kuss conducted a randomized trial to compare off-pump with on-pump coronary artery bypass grafting, which was sponsored in part by a grant from Medtronic, Düsseldorf, Germany. There was no external funding of the project reported, and all authors report no further conflicts of interest.

Received for publication April 28, 2009; revisions received July 30, 2009; accepted for publication Dec 9, 2009; available ahead of print Feb 18, 2010.

Address for reprints: Oliver Kuss, PhD, Institute of Medical Epidemiology, Biostatistics, and Informatics, Medical Faculty, University of Halle-Wittenberg, Magdeburger Str 8, 06097 Halle (Saale), Germany (E-mail: Oliver.Kuss@medizin.uni-halle. de).

0022-5223/\$36.00

Copyright (c) 2010 by The American Association for Thoracic Surgery doi:10.1016/j.jtcvs.2009.12.022
}

cardioplegia-induced cardiac arrest, the so-called on-pump technique. Although this technique is routinely used, there are still morbidity and mortality risks, attributed to a systemic inflammatory response and to atheromatous macroembolization. Because of these adverse side effects, the standard technique has been challenged in recent years by the emerging off-pump technique, which avoids the use of cardiopulmonary bypass and cardioplegia. The question of which method is superior is one of the most hotly debated and polarizing issues in cardiac surgery. ${ }^{2}$

Because of the public health and economic impacts of this question, a large number of randomized clinical trials (RCTs) were conducted. Most of them are summarized in systematic reviews. ${ }^{3,4}$ These systematic reviews show a trend toward an advantage of off-pump surgery in terms of the clinically relevant postoperative outcomes mortality, stroke, and myocardial infarction. The observed effects are not always found to be statistically significant, mostly because of limited sample sizes.

In addition to these RCTs, a number of nonrandomized trials have been conducted. The respective data were also collected in a systematic review. ${ }^{5}$ It is commonly agreed that results from observational studies should not be used for making treatment recommendations. Nonrandomized studies, however, avoid 2 important deficiencies of RCTs. First, RCTs are frequently conducted in highly selected patient groups, ${ }^{6}$ enrolling patients who are younger and 


$$
\begin{aligned}
& \text { Abbreviations and Acronyms } \\
& \begin{aligned}
\text { CABG } & =\text { coronary artery bypass grafting } \\
\text { CI } & =\text { confidence interval } \\
\text { OR } & =\text { odds ratio } \\
\text { RBC } & =\text { red blood cell } \\
\text { RCT } & =\text { randomized clinical trial }
\end{aligned}
\end{aligned}
$$

healthier than the average patient. ${ }^{7}$ Second, and this is of special concern in cardiac surgery, clinically relevant outcomes are only rarely observed. That is, RCTs intended to find differences between treatments require large sample sizes to detect differences between those rarely occurring outcomes. For example, a study designed to detect a postoperative mortality reduction from $3 \%$ to $2 \%$ with $80 \%$ power and $5 \%$ type I error would require more than 8000 patients. This number should be compared with the sample size of the largest RCTs published up to date, ${ }^{8}$ which included $388 \mathrm{pa}-$ tients. The number of patients included in the largest systematic review of RCTs to date was 5537 (from 66 trials). ${ }^{4}$ Therefore, not even the largest systematic reviews on this topic would have enough power to find the postulated difference in postoperative mortality.

Lack of randomization is of course the reason for distrusting observational studies as a basis for treatment recommendations. Randomization ensures that all relevant (known and unknown) prognostic and risk factors are balanced across treatment groups. In observational studies, we have to rely on statistical methods such as stratification, matching, or multivariate adjustment to adjust for baseline differences in treatment groups. A promising technique for this adjustment is the so-called propensity score method, which, if conducted with matching on the propensity score, achieves a kind of pseudorandomization. This ensures that at least the known and measured prognostic factors are balanced. The propensity score method, proposed as early as the 1980 s, ${ }^{9}$ has only recently been applied to clinical research, but sees increasing use, especially in cardiology and cardiac surgery. ${ }^{10}$ Moreover, there are indications that the propensity score method is statistically superior to the standard methods for multivariate adjustment, ${ }^{11,12}$ especially when the number of events is low as in CABG. ${ }^{12}$

In the following, we report on a systematic review and meta-analysis comparing off-pump and on-pump CABG explicitly including only propensity score analyses.

\section{MATERIALS AND METHODS \\ Search Strategy}

Searches were conducted independently by 2 persons (O.K., biostatistician; B.v.S., medical student) in the first week of February 2006. Our search strategy was 3-fold: First, we searched the literature databases MEDLINE, EMBASE, American College of Physicians Journal Club, Cochrane Central Register of Controlled Trials, Cochrane Database of Systematic Reviews,
Database of Abstracts of Reviews of Effects, EBM Reviews, and Web of Science for the keywords "Propensity" and "Off-Pump." Second, we analyzed the citations of 6 methodical articles ${ }^{9,13-17}$ on propensity score analysis via Web of Science (http://www.isiknowledge.com) because there is evidence that failure to use citation tracking may cause bias from overlooked studies. ${ }^{18}$ Third, we searched the open web-based scientific databases Google scholar (http://scholar.google.com), Scirus (http://www. scirus.com), and Vivísimo clustering (http://vivisimo.com), also with the keywords "Propensity" and "Off-Pump." Finally, we checked the references of all available articles. Meeting abstracts and unpublished reports were included. Authors of meeting abstracts were contacted by e-mail for additional information on the described studies. There were no restrictions on language or time of publication.

\section{Data Collection and Management}

Full-text versions of all initially retrieved publications were read independently by 2 reviewers (O.K., B.v.S.). Data were abstracted into a selfdeveloped case report form, which had been tested in a small pilot review encompassing 5 studies. The data collected by both reviewers were entered in a database, and disagreements were located by automatic comparisons. Agreement between reviewers was checked on a previously selected subgroup of abstracted items (inclusion of study, high-risk population, type of propensity analysis, reporting of confounders in the propensity score model). All disagreements on abstracted data were resolved by consensus and by discussion with a third reviewer (J.B.).

\section{Inclusion Criteria}

Studies were included in the meta-analysis if they reported a comparison of at least an off-pump with an on-pump group and made use of a propensity score analysis for comparing treatments. Randomized controlled trials, observational studies without a propensity score analysis, and systematic reviews with no new original data were excluded. For inclusion, studies also had to provide at least one of the binary clinical outcomes mortality, stroke, myocardial infarction, atrial fibrillation, renal failure, inotropic support, red blood cell (RBC) transfusion, wound infection, reoperation for bleeding, intraaortic balloon pump support, or prolonged ventilation. Only short-term or in-hospital outcomes were considered. Studies with mere experimental outcomes were excluded. We always kept the outcome definitions of the original researchers. Double publications were removed, but data from the same study populations were included if these populations did not completely overlap in the propensity score analyses.

\section{Statistical Methods}

For descriptive purposes, absolute and relative frequencies are reported for categoric variates. The odds ratio (OR) was used to describe treatment effects. From studies using regression adjustment or stratification in the propensity score analysis, the ORs with the corresponding confidence intervals (CIs) were extracted directly from the text. In studies with a matched propensity score analysis, we used the absolute numbers of events and calculated ORs with CIs using standard methods. Studies with zero events were corrected by the "reciprocal of the opposite treatment arm" method. ${ }^{19}$ In one study a relative risk was used to describe the treatment effect. Because ORs and relative risks are approximately equal for rare outcomes, we equated this relative risk with an OR.

For combining ORs from different studies, the random effects inversevariance method ${ }^{20}$ was applied, that is, ORs from the individual studies were combined as weighted averages. The random effects method, compared with the fixed effects method, was chosen because it allows heterogeneous treatment effects between studies and is slightly more conservative. However, as a sensitivity analysis, the fixed effects estimates are also presented. All calculations were performed with log-transformed ORs, and results were retransformed for presentation. Although it is well known that the inverse-variance method has deficiencies, we emphasize that it is the 
only method applicable with our approach where absolute numbers of events are only available in cases of matched propensity score analyses. To facilitate interpretation of results, we also computed summary numbers needed to treat (number needed to treat with off-pump surgery to avoid 1 additional event) for each clinical outcome. Numbers needed to treat were derived from the combined ORs using the ideas of Zhang and $\mathrm{Yu}^{21}$ The required baseline risk data were calculated from the studies that reported a matched propensity score analysis, because absolute frequencies are only available in these cases. To assess heterogeneity between studies, we performed the standard test for homogeneity (based on Cochran's Q) ${ }^{20}$ and the recently proposed $\mathrm{I}^{2}$ statistic.

Meta-regression on location of study (Northern America vs others), type of propensity score analysis (matching vs nonmatching), population risk (high risk vs standard risk), volume per year (defined as the number of patients divided by the length of the observation period, but only in single-center studies), and percentage of off-pump cases in the general study population (not necessarily equal to this percentage in the propensity score population) was conducted to judge the influence of these factors on heterogeneity. For this meta-regression, all outcomes were combined in a single data set, and the analysis was adjusted for correlated (within study) outcomes by using a random effects model. ${ }^{20}$ All statistical estimates are given with their $95 \%$ CIs. The study database was programmed in Microsoft ACCESS (Microsoft Corp, Redmond, Wash), and all statistical analyses were conducted with SAS, 9.1.2. (SAS Institute Inc, Cary, NC).

\section{RESULTS}

The initial search yielded 58 publications, of which 39 $(66 \%)$ were found in the described literature databases, 8 $(14 \%)$ were found by citation tracking, and $11(19 \%)$ were found in the open scientific databases.

Thirty-five of the initial 58 publications $(60 \%)$ were included in the final analyses (Table E1), $24(69 \%)$ from the described literature databases, $3(9 \%)$ from citation tracking, and $8(22 \%)$ from the open scientific databases (Figure 1). Five publications were excluded because they did not compare an off-pump with an on-pump group; 6 publications were excluded because they made no or wrong use of the propensity score method; and 4 publications were systematic reviews without new original data. In 6 publications, no information was given on the prespecified outcomes, and in 1 publication results from the propensity score analysis were given only narratively. One publication was removed because of double publication.

Table 1 provides an overview of the included studies: Sixteen studies $(46 \%)$ were conducted in Europe, and the remaining were conducted in Northern America. Authors of 19 propensity score analyses $(54 \%)$ reported on a highrisk population. The 35 studies account for a total of 123,137 observations; 49,718 procedures $(40.4 \%)$ were conducted off-pump. The online supplement shows the estimated ORs for the single studies numerically (Table E2) and graphically (Figure E1).

Table 2 reports the results of the meta-analyses for the specific outcomes. For all 11 outcomes we find an estimated OR less than 1 in favor of off-pump surgery. This effect is highly significant $(P<.0001)$ for the outcomes mortality, stroke, renal failure, and RBC transfusion; significant for

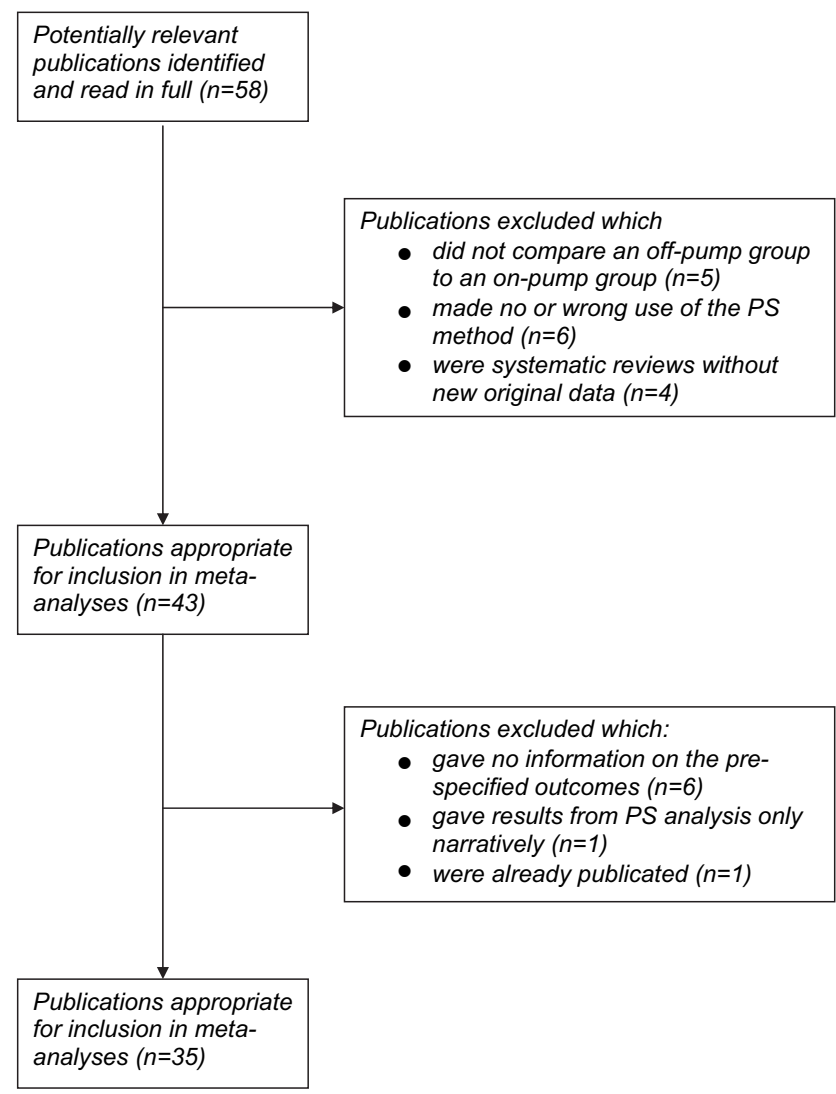

FIGURE 1. Flow diagram of initially retrieved and eventually included studies. PS, Propensity score.

wound infection $(P<.001)$, prolonged ventilation $(P<$ $.01)$, intraaortic balloon pump support $(P=.01)$ and inotropic support $(P=.02)$; and borderline significant for reoperation for bleeding $(P=.06)$. Insignificant ORs near 1 were observed for myocardial infarction and atrial fibrillation. Estimates from the fixed effects model differed only slightly from the random effect estimates. Heterogeneity of studies for the different outcomes varied widely. A very large heterogeneity was found for the outcomes inotropic support and RBC transfusion, and large heterogeneity for reoperation and atrial fibrillation. All other outcomes showed at most moderate or no heterogeneity.

In meta-regression, heterogeneity of treatment effects could not be explained by the study location (Northern America vs Europe, $P=.33$ ), type of propensity score analysis (matching vs nonmatching, $P=.99$ ), population risk (high risk vs standard, $P=.65)$, volume per year $(P=$ $.55)$, or percentage of off-pump cases in the general study population $(P=.25)$.

\section{DISCUSSION}

Our systematic review and meta-analysis of propensity score analyses finds off-pump surgery superior to on-pump surgery with respect to all of the assessed short-term 


\begin{tabular}{|c|c|c|c|c|c|c|c|c|}
\hline Study & $\begin{array}{c}\text { Observation } \\
\text { period }\end{array}$ & $\begin{array}{c}\text { Study } \\
\text { location }\end{array}$ & $\begin{array}{c}\text { Study } \\
\text { centers (no.) }\end{array}$ & $\begin{array}{c}\text { from a high-risk } \\
\text { group } \\
\text { (as reported from } \\
\text { the authors)? } \\
\text { If yes, which risk? }\end{array}$ & $\begin{array}{c}\text { Average patient } \\
\text { age, } y\end{array}$ & $\begin{array}{c}\text { Gender } \\
(\% \text { male }) \\
\end{array}$ & $\begin{array}{c}\text { Proportion of } \\
\text { off-pump } \\
\text { cases }(\%) \\
\end{array}$ & $\begin{array}{c}\text { Proportion of } \\
\text { off-pump } \\
\text { cases }(\%) \\
\end{array}$ \\
\hline Ascione 2002 & $04 / 96-04 / 01$ & England & 1 & Overweight $(\mathrm{BMI} \geq 25)$ & 63.0 & 79.5 & $23.7(674 / 2844)$ & $23.7(674 / 2844)$ \\
\hline Ascione 2003 & $04 / 96-08 / 02$ & England & 1 & Severe LV dysfunction $(\mathrm{EF}<30 \%)$ & 65.3 & 90.4 & $29.6(74 / 250)$ & $29.6(74 / 250)$ \\
\hline Boening 2003 & $01 / 98-12 / 01$ & Germany & 1 & No & 65.5 & - & $42.6(72 / 169)$ & $20.5(133 / 650)$ \\
\hline Calafiore 2003a & $11 / 94-12 / 01$ & Italy & 1 & No & 64.4 & 83.2 & $50.0(961 / 1922)$ & - \\
\hline Calafiore $2003 b$ & $11 / 94-12 / 01$ & Italy & 1 & EuroSCORE $\geq 6$ & 70.1 & 71.7 & $50.0(510 / 1020)$ & - \\
\hline Calafiore 2005 & $11 / 94-12 / 01$ & Italy & 1 & No & 62.6 & 86.1 & $50.0(597 / 1194)$ & - \\
\hline Chukwuemeka 2005 & $00 / 95-00 / 03$ & Canada & 1 & Preoperative renal dysfunction & 70.3 & 64.4 & $25.0(146 / 584)$ & $5.5(158 / 2869)$ \\
\hline Frankel 2005 & $01 / 98-06 / 02$ & USA & 1 & No & - & - & $50.0(2141 / 4282)$ & $41.2(3646 / 8843)$ \\
\hline Grunkemeier 2002 & $00 / 98-00 / 00$ & USA & 9 & No & 66.5 & 73.1 & $31.8(990 / 3110)$ & $15.0(1194 * / 7955)$ \\
\hline Ivanov 2006 & $00 / 96-00 / 02$ & Canada & 1 & No & - & - & $50.0(503 / 1006)$ & $4.5(514 / 11368)$ \\
\hline Karthik 2003 & $04 / 97-03 / 02$ & England & 2 & Nonelective CABG & 65.0 & 72.4 & $50.4(417 / 828)$ & $48.1(1813 / 3771)$ \\
\hline Karthik 2004 & $04 / 97-03 / 02$ & England & 2 & Peripheral vascular disease & 65.6 & 79.4 & $50.0(211 / 422)$ & $48.1(1813 / 3771)$ \\
\hline Lamy 2005 & $03 / 01-12 / 02$ & Canada & 14 & No & 64.6 & - & $50.0(1233 / 2466)$ & $49.5(1657 / 3350)$ \\
\hline Lee 2006 & 07/99-01/04 & Canada & 1 & No & - & - & $50.0(165 / 330)$ & $48.1(290 / 603)$ \\
\hline Lu 2005 & $04 / 97-04 / 03$ & Great Britain & 1 & LMS disease & 65.7 & 80.5 & $21.6(259 / 1197)$ & $21.6(259 / 1197)$ \\
\hline Mack 2004a & 00/99-00/01 & USA & 4 & Multivessel disease & - & - & $50.0(5774 / 11548)$ & $41.9(7283 / 17401)$ \\
\hline Mack 2004b & 01/98-03/02 & USA & 82 & Women & 68.8 & 0.0 & $50.0(3688 / 7376)$ & $19.4(4250 / 21902)$ \\
\hline Magee 2002 & 01/98-07/00 & USA & 2 & Multivessel disease & - & - & $33.3(1606 * / 4818)$ & $23.5(1983 / 8449)$ \\
\hline Magee 2003 & $01 / 99-12 / 00$ & USA & - & $>2$ grafts & 68.0 & 68.6 & $50.0(16937 / 33874)$ & $8.8(17969 / 204602)$ \\
\hline Meco 2004 & - & Italy & - & Age $>75 y$ & - & - & $65.5(78 / 119)$ & - \\
\hline Oo 2003 & 04/97-09/02 & England & 1 & EuroSCORE $\geq 6$ & 71.4 & 72.6 & $50.4(196 / 389)$ & - \\
\hline Pandey 2005 & 04/97-09/02 & England & 1 & No & 61.9 & 80.8 & $50.0(360 / 720)$ & $17.4(987 / 5679)$ \\
\hline Patel 2002a & 04/97-05/01 & England & 2 & No & 62.0 & 78.1 & $48.0(1117 / 2327)$ & $48.0(1117 / 2327)$ \\
\hline Patel 2002b & 04/97-03/01 & England & 4 & No & 62.8 & 79.1 & $7.7(843 / 10941)$ & $7.7(843 / 10941)$ \\
\hline Sabik 2002 & 01/97-06/00 & USA & 1 & No & 66.0 & 69.5 & $50.0(406 / 812)$ & $13.0(481 / 3712)$ \\
\hline Saunders 2004 & $00 / 96-00 / 02$ & USA & 1 & Functional mitral regurgitation & - & - & $50.0(127 / 254)$ & $20.6(222 / 1078)$ \\
\hline Seif 2005 & $00 / 93-00 / 04$ & USA & 1 & No & - & - & $25.0(1913 / 7641)$ & - \\
\hline Sharony 2004 & 06/93-10/02 & USA & 1 & Atheromatous aortic disease & 73.0 & 68.8 & $50.0(245 / 490)$ & $28.5(281 / 985)$ \\
\hline Srinivasan 2004 & $04 / 97-09 / 02$ & England & 1 & Diabetes & 65.2 & 77.0 & $19.6(186 / 951)$ & $19.6(186 / 951)$ \\
\hline Stamou 2002 & $06 / 94-12 / 00$ & USA & 1 & No & - & - & $50.0(1670 / 3340)$ & $22.3(2320 / 10389)$ \\
\hline Stamou 2004 & $10 / 98-06 / 01$ & USA & 1 & No & - & - & $50.0(1833 * / 3666 *)$ & $44.6(2477 / 5554)$ \\
\hline Stamou 2005 & $01 / 00-12 / 00$ & USA & 1 & Parsonnet score $\geq 20$ points & 71.0 & 48.3 & $61.4(315 / 513)$ & $61.4(315 / 513)$ \\
\hline Stamou 2006 & $01 / 00-10 / 03$ & USA & 2 & Nonelective CABG & - & - & $50.0(2013 / 4026)$ & $36.3(2273 / 6260)$ \\
\hline Weerasinghe 2005 & 01/01-11/03 & England & 3 & Multivessel disease & 64.5 & 73.7 & $40.0(817 / 2041)$ & $40.0(817 / 2041)$ \\
\hline Williams 2005 & 01/98-09/03 & USA & 1 & No & 63.5 & 69.8 & $11.3(641 / 5667)$ & $11.3(641 / 5667)$ \\
\hline
\end{tabular}

PS analysis population

General population

$B M I$, Body mass index; $L V$, left ventricular; $E F$, ejection fraction; $C A B G$, coronary artery bypass grafting; $L M S$, left main stem stenosis. *Numbers estimated from the text. 
TABLE 2. Results of meta-analyses

\begin{tabular}{|c|c|c|c|c|c|c|}
\hline Response & $\begin{array}{l}\text { No. of studies } \\
\text { (patients) }\end{array}$ & OR $(95 \%$ CI $) P$ value, REM & $\begin{array}{c}P \text { value } \\
\text { homogeneity }\end{array}$ & $\mathbf{I}^{2}(\%)$ & NNT $(95 \%$ CI $)$ & OR $(95 \%$ CI $) P$ value, FEM \\
\hline Mortality & $28(100,066)$ & $0.69(0.60-0.75) P<.0001$ & .18 & 14 & $189(155-251)$ & $0.70(0.65-0.76) P<.0001$ \\
\hline Stroke & $22(55,290)$ & $0.42(0.33-0.54) P<.0001$ & .16 & 16 & $104(90-132)$ & $0.49(0.41-0.58) P<.0001$ \\
\hline Myocardial infarction & $14(35,951)$ & $0.97(0.73-1.30) P=.86$ & .06 & 32 & $2685(254$ to -229$)$ & $0.91(0.74-1.11) P=.35$ \\
\hline Atrial fibrillation & $11(29,343)$ & $0.92(0.80-1.05) P=.20$ & .01 & 51 & 79 (33 to -143$)$ & $0.85(0.80-0.91) P<.0001$ \\
\hline Renal failure & $17(38,866)$ & $0.60(0.51-0.70) P<.0001$ & .21 & 11 & $82(67-110)$ & $0.59(0.53-0.66) P<.0001$ \\
\hline Inotropic support & $7(6,153)$ & $0.59(0.38-0.90) P=.02$ & $P<.0001$ & 82 & $8(5-41)$ & $0.65(0.56-0.75) P<.0001$ \\
\hline RBC transfusion & $8(16,685)$ & $0.36(0.25-0.54) P<.0001$ & $P<.0001$ & 91 & $9(7-13)$ & $0.49(0.44-0.54) P<.0001$ \\
\hline Wound infection & $13(33,030)$ & $0.59(0.45-0.77) P<.001$ & .97 & 0 & $314(235-553)$ & $0.59(0.45-0.77) P<.0001$ \\
\hline Reoperation for bleeding & $14(39,480)$ & $0.76(0.57-1.02) P=.06$ & $<.01$ & 50 & $195(107$ to -2753$)$ & $0.69(0.59-0.81) P<.0001$ \\
\hline IABP support & $7(9703)$ & $0.60(0.41-0.89) P=.01$ & .18 & 10 & $245(164-904)$ & $0.57(0.43-0.76) P<.001$ \\
\hline Prolonged ventilation & $6(8675)$ & $0.71(0.56-0.89) P<.01$ & .32 & 0 & $116(77-312)$ & $0.74(0.61-0.90) P=.002$ \\
\hline
\end{tabular}

outcomes. This advantage was statistically significant and clinically relevant for most outcomes, especially for the most valid outcome of mortality. This study is the first to systematically collect evidence only from propensity score analyses, a statistical technique for analyzing nonrandomized trials that finds increasing use in cardiac surgery and that is especially suited for situations with rare outcomes.

Our results have to be compared with the existing knowledge on the topic, especially with previous meta-analyses of randomized $^{3-5}$ and nonrandomized trials ${ }^{5}$ (Figure 2). It should be noted that there is only a small overlap $(n=7)$ of our studies and the observational studies included in Wijeysundera and colleagues ${ }^{5}$ review. As such, our results can be considered roughly independent of Wijeysundera and colleagues' results. Compared with the results of randomized trials, our results are not contradictory; our estimates are well within the CIs of estimates from randomized trials. Of course, CIs from RCTs are larger, reflecting smaller

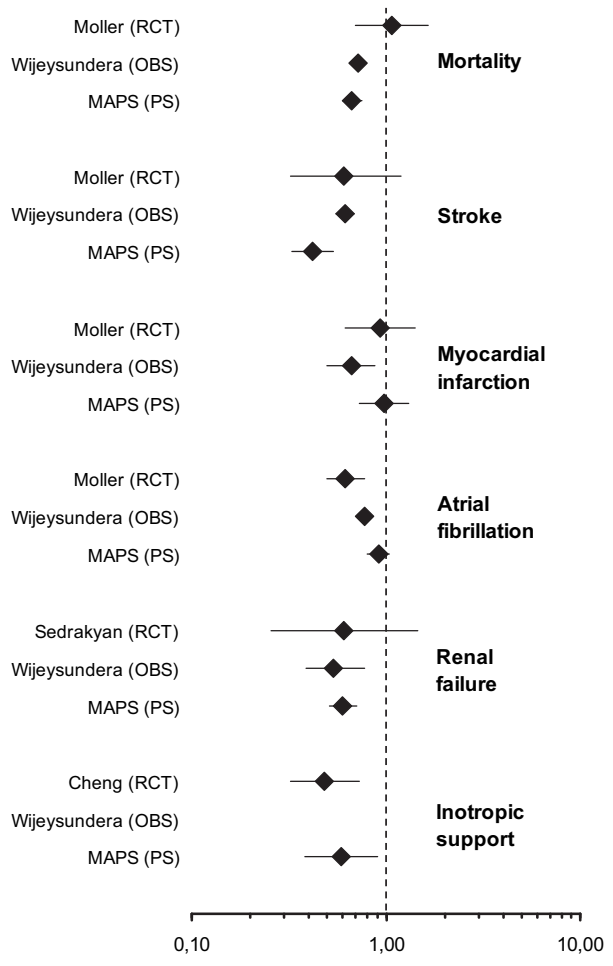

Odds Ratio (with $95 \%-\mathrm{CI}$ )

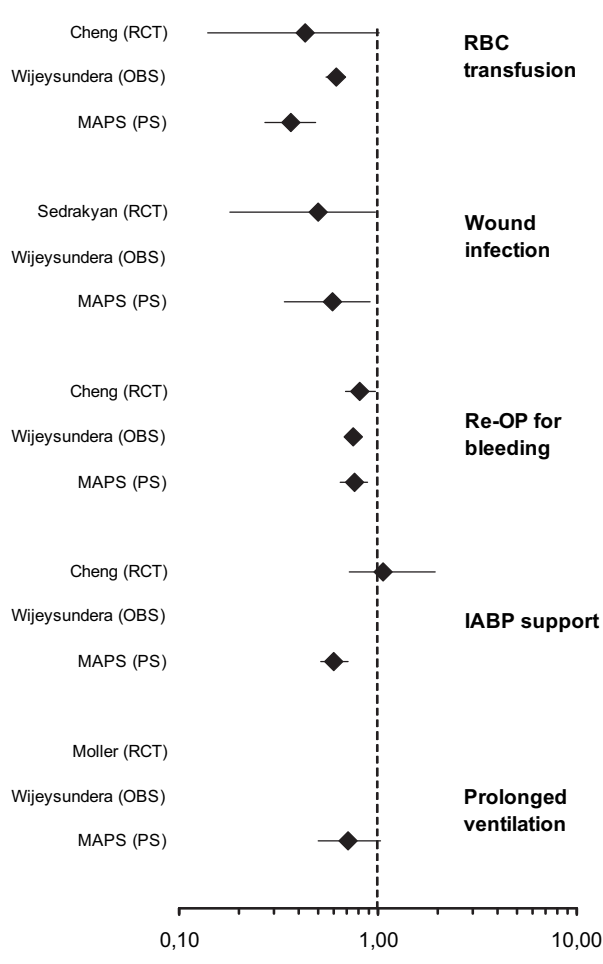

Odds Ratio (with $95 \%-\mathrm{Cl}$ )

FIGURE 2. Results from previous meta-analyses of RCTs, observational studies, and our propensity-score analyses for all our prespecified outcomes. For the meta-analyses of RCTs, we give the results from the most recent meta-analyses. Results are shown as ORs with $95 \%$ CIs. In cases for which the previous meta-analyses reported relative risks, we recalculated the OR by using the formula of Zhang and $\mathrm{Yu} .{ }^{21} R C T$, Randomized clinical trial; $O B S$, observational study; $P S$, propensity score; $R B C$, red blood cell; $O P$, operation; $I A B P$, intraaortic balloon pump; $C I$, confidence interval. 
sample sizes. We also expect randomized trials to be performed in selected populations, and certain differences between RCTs and our propensity score analyses are not surprising. Compared with previous nonrandomized trials, there is agreement in most of the outcomes. But we also find a nonoverlapping CI for stroke and only succinct overlapping intervals for atrial fibrillation and RBC transfusion. It should be noted, however, that the large sample sizes in both Wijeysundera and colleagues' review and our study guarantee small CIs, and not all significant differences can be considered clinically relevant.

Our systematic review, which is the first to explicitly include only propensity score analyses, also contributes to the body of methodical knowledge. Only approximately $70 \%$ of the studies were found in the standard literature databases. This underlines the importance of a free web search and, especially important for propensity score analyses, citation tracking of classic articles describing the propensity score method. We were not surprised by the results of our meta-regression on the influence of type of propensity score analysis. Although current guidelines favor the use of matching, ${ }^{22}$ we found no differences between studies using matching and those using other techniques for adjusting for the propensity score. This was already stressed in the initial propensity score article by Rosenbaum and Rubin. ${ }^{9}$ However, and somewhat contrary to common perception, there were no differences in effects from high-risk and low-risk populations.

Any systematic review and meta-analysis is vulnerable to publication bias, that is, the selective reporting of trials depending on study results. Funnel plots were proposed to graphically assess publication bias. We drew funnel plots for all our outcomes. All plots indicated no publication bias (Figure E2). Moreover, because the comparison between off- and on-pump in CABG is such a hotly debated issue, ${ }^{2}$ we expect most (or hopefully all) of the studies to be submitted and published, as predicted by Sedrakyan and colleagues. ${ }^{3}$

\section{Study Limitations}

Our study has some limitations. We reported only shortterm outcomes; data on graft patency or revascularization rates are missing. This is problematic because new evidence suggests that the on-pump technique may result in better graft patency. ${ }^{23}$ Graft patency data were omitted because they are rarely reported, and patients frequently are lost to follow-up.

It is tempting to speculate why most of the CABG procedures are still performed on-pump. Off-pump surgery is technically more demanding than the on-pump technique performed under cardioplegic arrest. Only a small number of centers train their staff in the former technique. Therefore, off-pump surgery is part of just a limited number of a surgeon's armamentarium. This contrasts with the experience in other centers, for example, Emory University in Atlanta, where more than $80 \%$ of surgical revascularizations are performed off-pump. ${ }^{24}$ In countries such as Japan or India, the percentage is greater than $50 \%{ }^{25}$ Authors from these countries have demonstrated that an off-pump program can be established without risk and with good patient outcomes. As we show in our article, the evidence remains ambiguous at this time. This is also reflected in the American Heart Association's scientific statement article. ${ }^{2}$ Lack of a compelling indication is certainly a significant reason for not abandoning the standard technique in favor of one that is highly challenging.

\section{CONCLUSIONS}

Current evidence from nonrandomized trials of any design suggests that off-pump CABG is superior, at least with respect to short-term outcomes. This finding is in line with the collected evidence from the present randomized trials. In the future, large ongoing randomized trials, among them the CORONARY trial from Canada (4700 patients planned, expected end of recruiting phase: May 2014, ClinicalTrials.gov Identifier: NCT00463294) and the ROOBY trial ${ }^{26}$ (2200 patients planned, expected end of recruiting phase: November 2008) will contribute to the definite answer. Long-term follow-up of patients from current trials will provide additional evidence.

The authors thank Lena Minning, Mareike Kunze, and Jörn Klauke (Institute of Medical Epidemiology, Biostatistics, and Informatics, Faculty of Medicine, University of Halle-Wittenberg, Halle [Saale], Germany) for designing and programming the study database.

\section{References}

1. Mohr DN, Bauer J, Döbler K, Eckert O, Fischer B, Woldenga C. Qualität sichtbar machen. BQS Qualitätsreport 2005. Düsseldorf: BQS Bundesgeschäftsstelle Qualitätssicherung gGmbH; 2006.

2. Sellke FW, DiMaio JM, Caplan LR, Ferguson TB, Gardner TJ, Hiratzka LF, et al. Comparing on-pump and off-pump coronary artery bypass grafting: numerous studies but few conclusions: a scientific statement from the American Heart Association council on cardiovascular surgery and anesthesia in collaboration with the interdisciplinary working group on quality of care and outcomes research. Circulation. 2005; 111:2858-64.

3. Sedrakyan A, Wu AW, Parashar A, Bass EB, Treasure T. Off-pump surgery is associated with reduced occurrence of stroke and other morbidity as compared with traditional coronary artery bypass grafting: a meta-analysis of systematically reviewed trials. Stroke. 2006;2759-69.

4. Moller CH, Penninga L, Wetterslev J, Steinbruchel DA, Gluud C. Clinical outcomes in randomized trials of off- vs on-pump coronary artery bypass surgery: systematic review with meta-analyses and trial sequential analyses. Eur Heart J. 2008;29:2601-16.

5. Wijeysundera DN, Beattie WS, Djaiani G, Rao V, Borger MA, Karkouti K, et al. Off-pump coronary artery surgery for reducing mortality and morbidity: metaanalysis of randomized and observational studies. J Am Coll Cardiol. 2005;46: 872-82.

6. Rothwell PM. External validity of randomised controlled trials: " to whom do the results of this trial apply?' Lancet. 2005;365:82-93.

7. Britton A, McKee M, Black N, McPherson K, Sanderson C, Bain C. Choosing between randomised and non-randomised studies: a systematic review. Health Technol Assess. 1998;2:i-124. 
8. Straka Z, Widimsky P, Jirasek K, Stros P, Votava J, Vanek T, et al. Off-pump versus on-pump coronary surgery: final results from a prospective randomized study PRAGUE-4. Ann Thorac Surg. 2004;789-93.

9. Rosenbaum PR, Rubin DB. The central role of the propensity score in observational studies for causal effects. Biometrika. 1983;70:41-55.

10. Sturmer T, Joshi M, Glynn RJ, Avorn J, Rothman KJ, Schneeweiss S. A review of the application of propensity score methods yielded increasing use, advantages in specific settings, but not substantially different estimates compared with conventional multivariable methods. J Clin Epidemiol. 2006;59:437-47.

11. Cook EF, Goldman L. Performance of tests of significance based on stratification by a multivariate confounder score or by a propensity score. J Clin Epidemiol.1989;42:317-324.

12. Cepeda MS, Boston R, Farrar JT, Strom BL. Comparison of logistic regression versus propensity score when the number of events is low and there are multiple confounders. Am J Epidemiol. 2003;158:280-7.

13. Rosenbaum PR, Rubin DB. Reducing bias in observational studies using subclassification on the propensity score. J Am Stat Assoc. 1984;79:516-24.

14. Rubin DB. Estimating causal effects from large data sets using propensity scores. Ann Intern Med. 1997;127:757-63.

15. Joffe MM, Rosenbaum PR. Invited commentary: propensity scores. Am J Epidemiol. 1999;150:327-33.

16. D'Agostino RB. Propensity score methods for bias reduction in the comparison of a treatment to a non-randomized control group. Stat Med. 1998;17:2265-81.

17. Blackstone EH. Comparing apples and oranges. J Thorac Cardiovasc Surg. 2002; 123:8-15.
18. Kuper H, Nicholson A, Hemingway H. Searching for observational studies: what does citation tracking add to PubMed? A case study in depression and coronary heart disease. BMC Med Res Methodol. 2006;6:4.

19. Sweeting MJ, Sutton AJ, Lambert PC. What to add to nothing? Use and avoidance of continuity corrections in meta-analysis of sparse data. Stat Med. 2004;23:1351-75.

20. Sutton AJ, Abrams KR, Jones DR, Sheldon TA, Song F. Methods for metaanalysis in medical research. In: Cressie NAC, Fisher NI, Johnstone IM, Kadane JB, Scott DW, Silverman BW, et al, eds. Wiley series in probability and statistics. Chichester: Wiley; 2000:1-317.

21. Zhang J, Yu KF. What's the relative risk? A method of correcting the odds ratio in cohort studies of common outcomes. JAMA. 1998;280:1690-1.

22. Austin PC. Propensity-score matching in the cardiovascular surgery literature from 2004 to 2006: a systematic review and suggestions for improvement. $J$ Thorac Cardiovasc Surg. 2007;134:1128-35

23. Takagi H, Tanabashi T, Kawai N, Kato T, Umemoto T. Off-pump coronary artery bypass sacrifices graft patency: meta-analysis of randomized trials. J Thorac Cardiovasc Surg. 2007; 133:e2-e3.

24. Song HK, Petersen RJ, Sharoni E, Guyton RA, Puskas JD. Safe evolution towards routine off-pump coronary artery bypass: negotiating the learning curve. Eur $J$ Cardiothorac Surg. 2003;24:947-52.

25. Sezai Y, Orime Y, Tsukamoto S. Coronary artery surgery results 2005 in Japan. Ann Thorac Cardiovasc Surg. 2007;13:220-3.

26. Novitzky D, Shroyer AL, Collins JF, McDonald GO, Lucke J, Hattler B, et al. A study design to assess the safety and efficacy of on-pump versus off-pump coronary bypass grafting: the ROOBY trial. Clin Trials. 2007;4:81-91. 

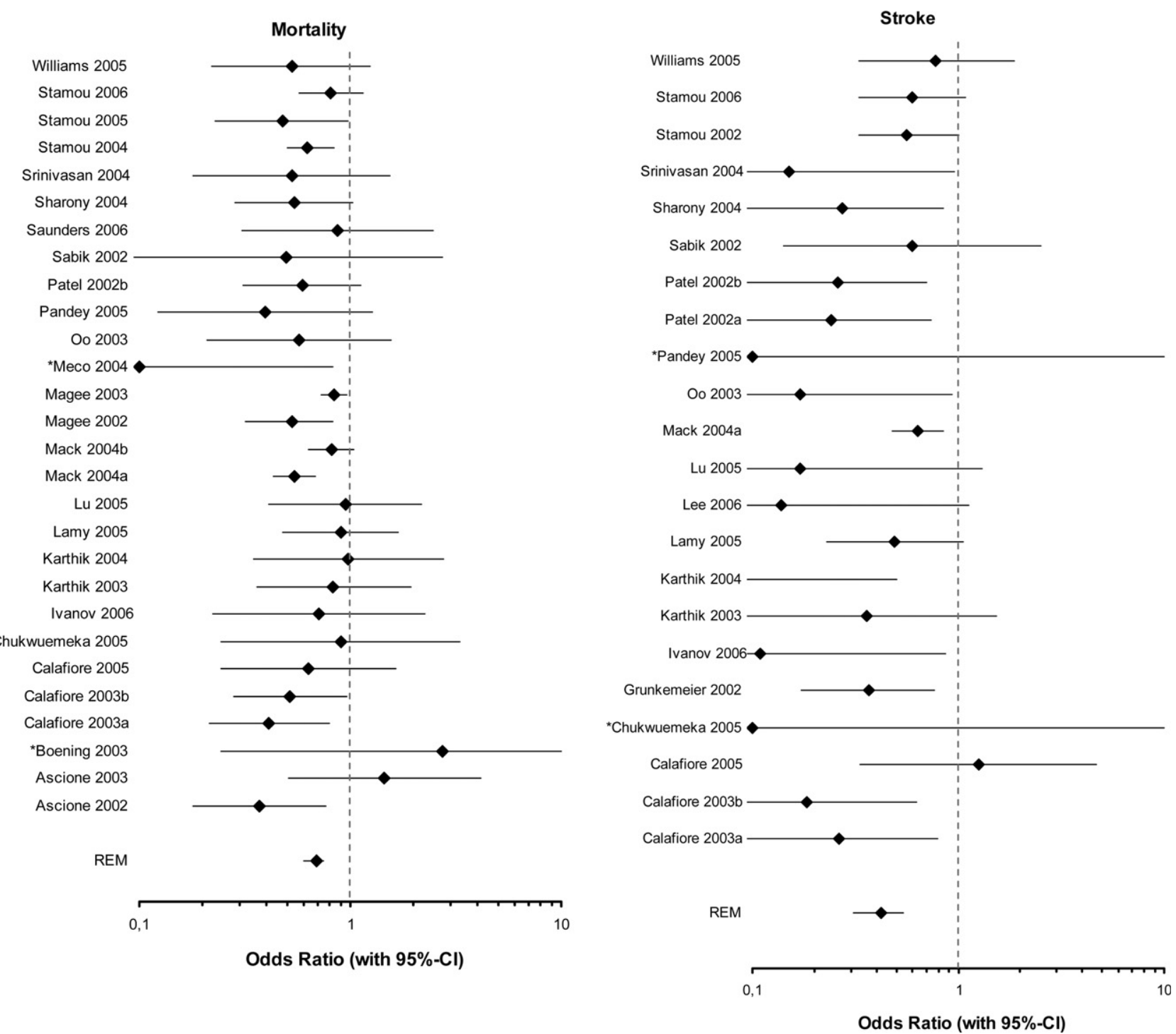

FIGURE E1. Forest plots for all outcomes. To enhance readability, $\mathrm{x}$-axes are only drawn from 0.1 to 10 . CIs having values outside this range are marked by an asterisk (*). $C I$, Confidence interval; $R B C$, red blood cell; $I A B P$, intraaortic balloon pump. 

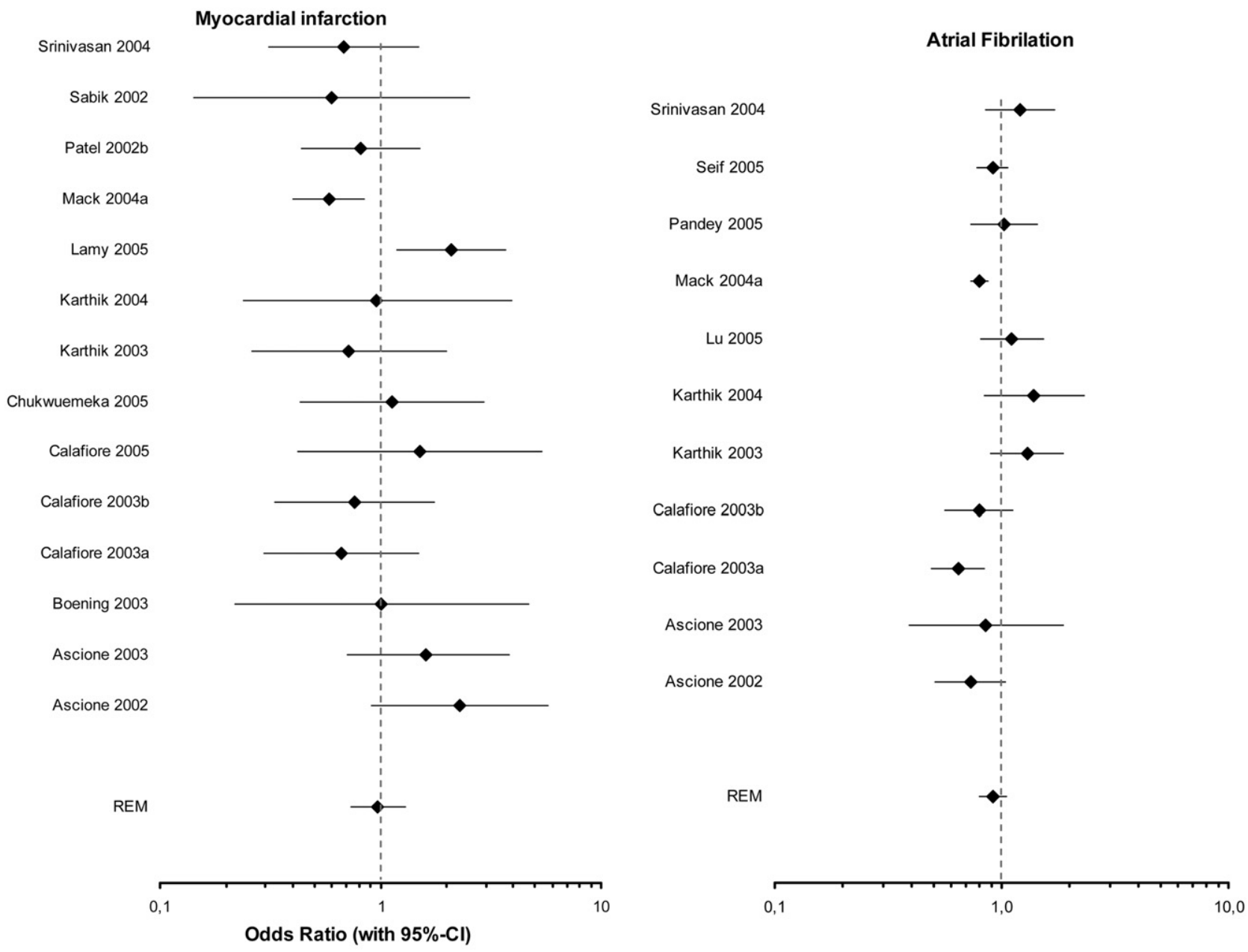

Odds Ratio (with 95\%-Cl)

FIGURE E1. Continued 
Renal failure

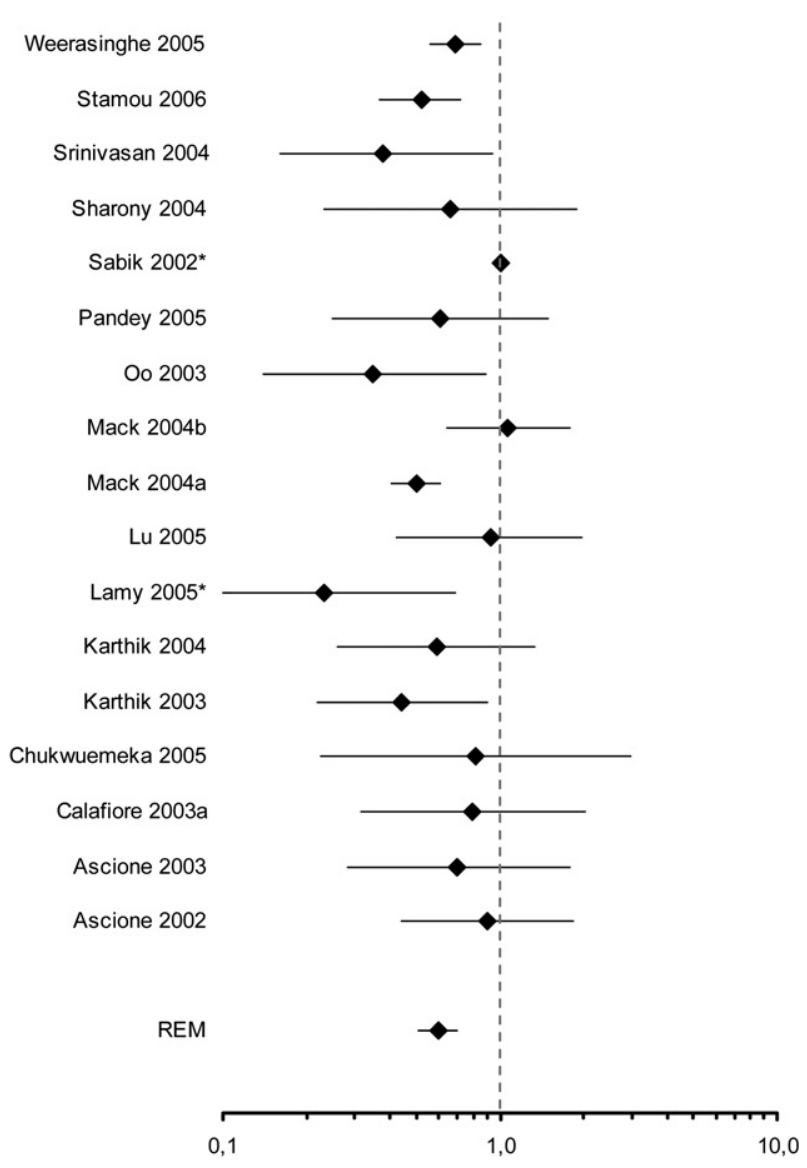

Odds Ratio (with 95\%-Cl)
Inotropic support

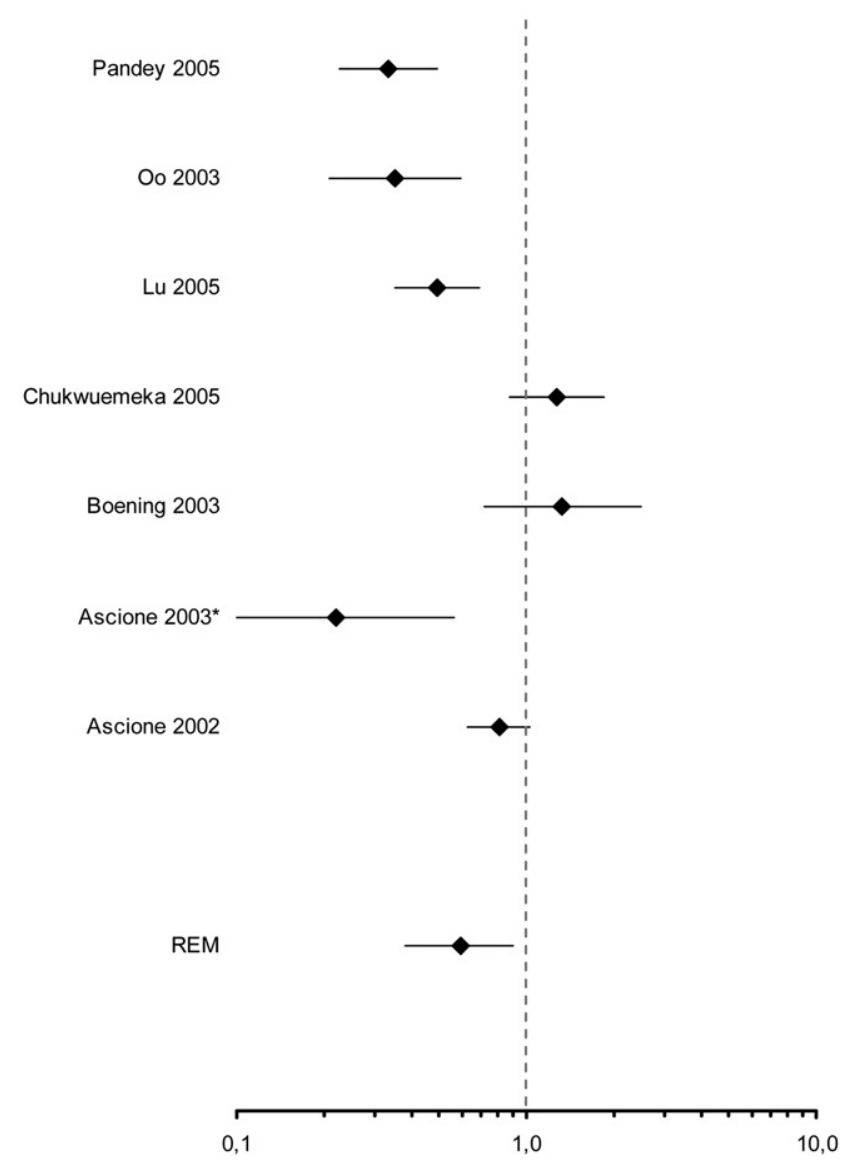

Odds Ratio (with $95 \%-\mathrm{Cl}$ )

FIGURE E1. Continued 


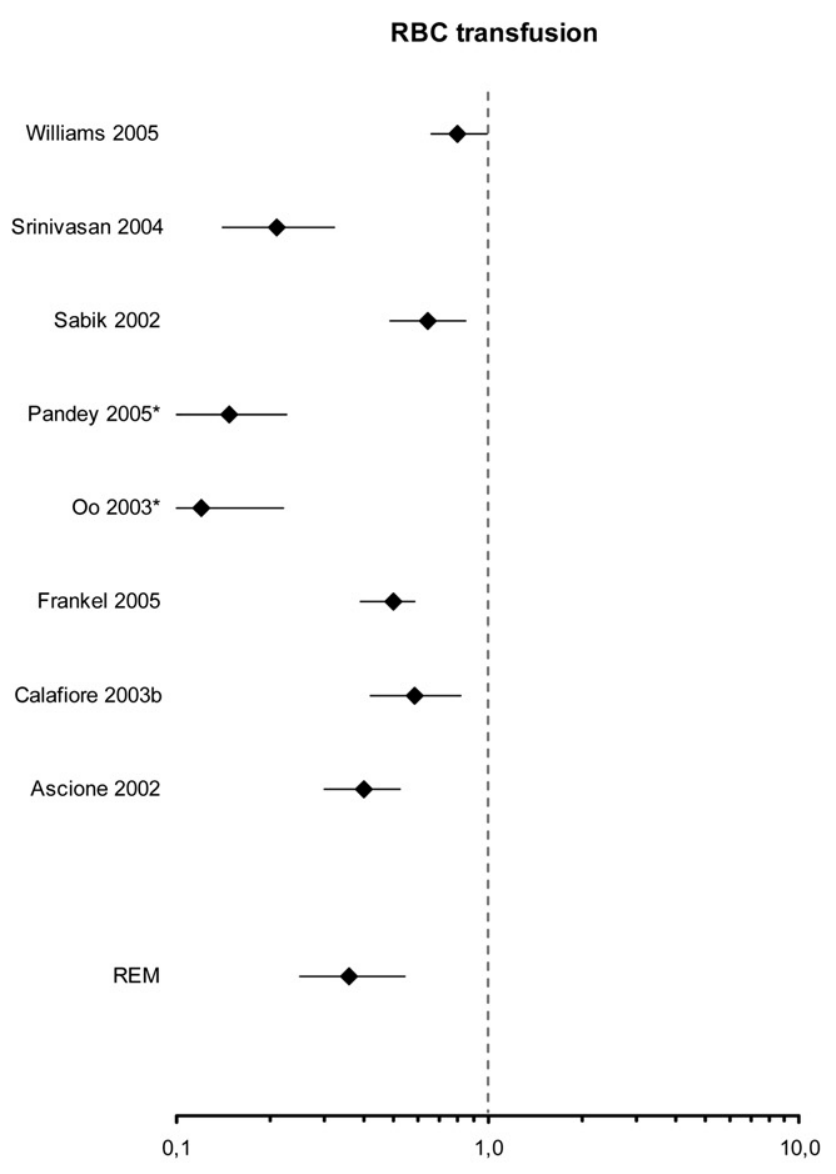

Odds Ratio (with 95\%-Cl)
Wound infection

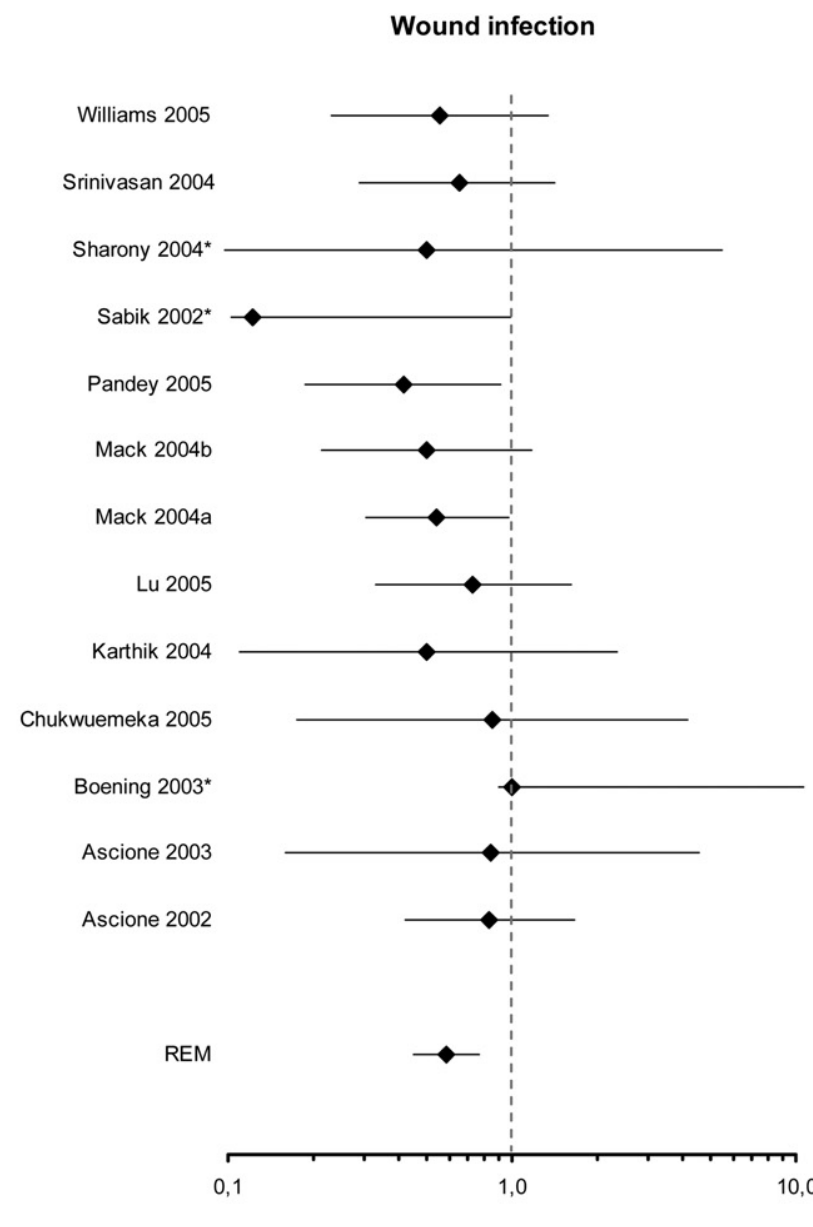

Odds Ratio (with $95 \%-\mathrm{Cl})$

FIGURE E1. Continued 
Re-operation for bleeding

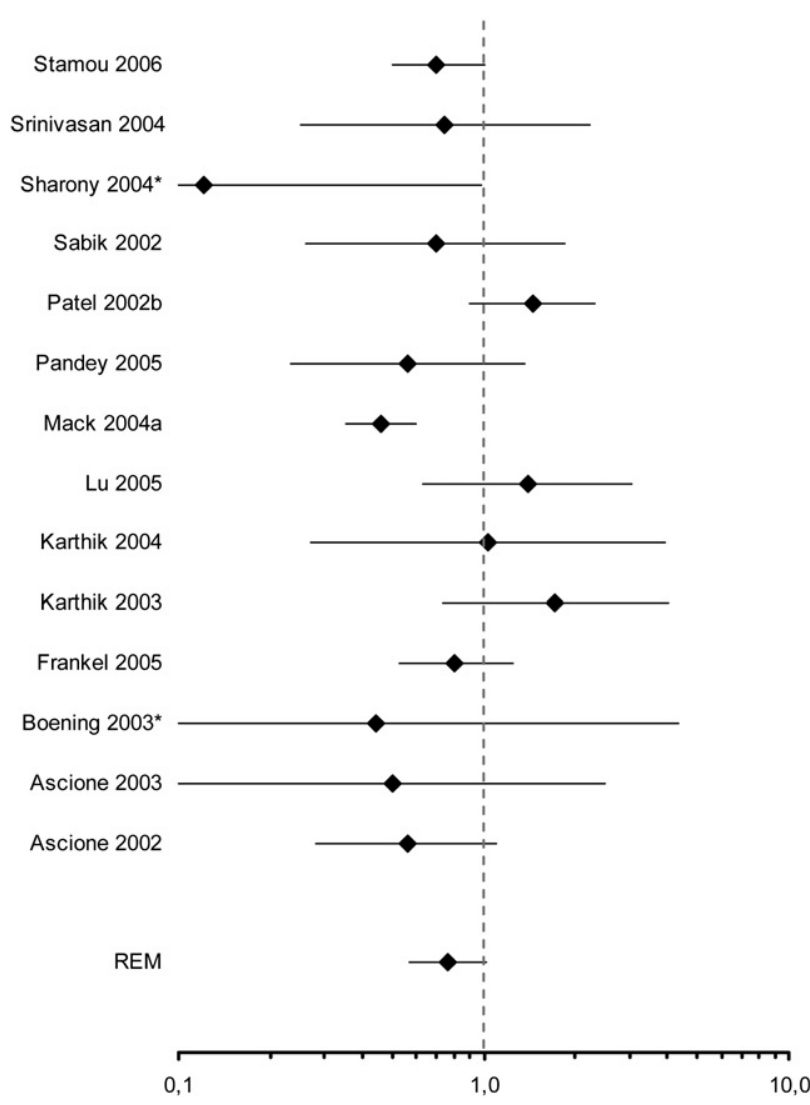

Odds Ratio (with 95\%-Cl)

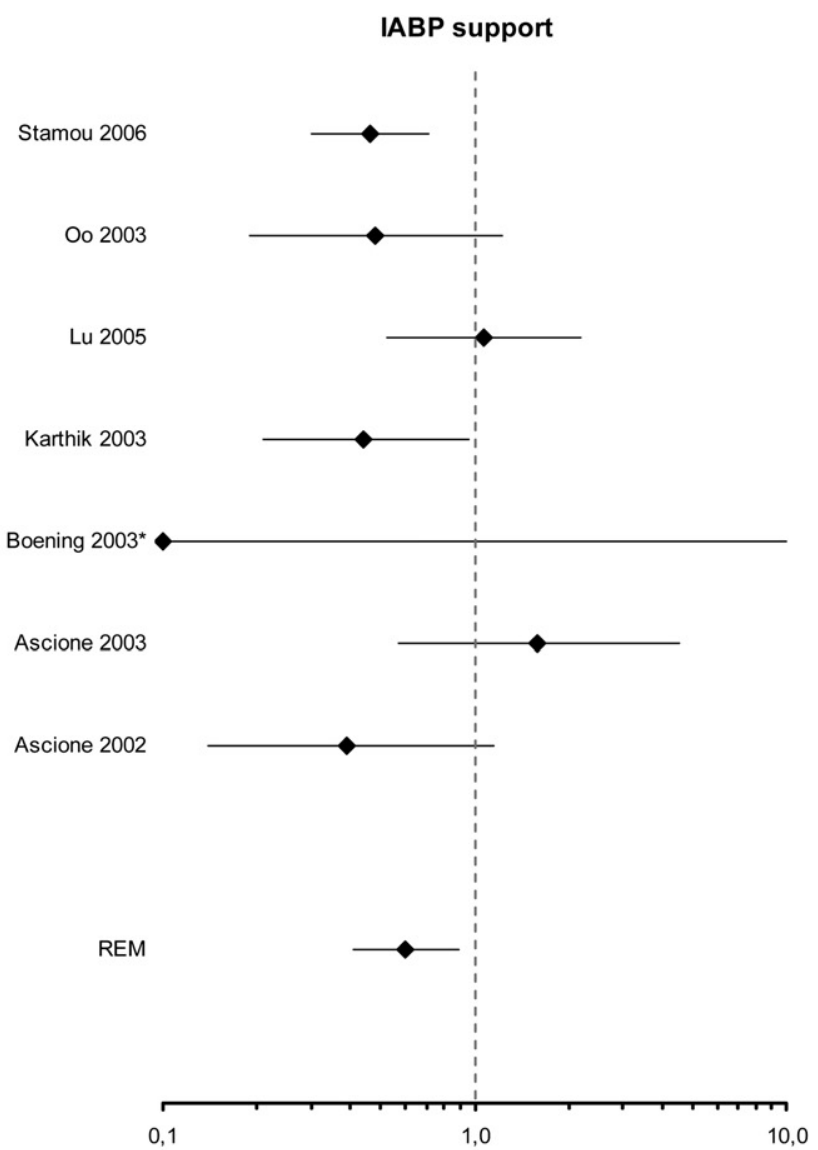

Odds Ratio (with 95\%-CI)

FIGURE E1. Continued 
Prolonged ventilation

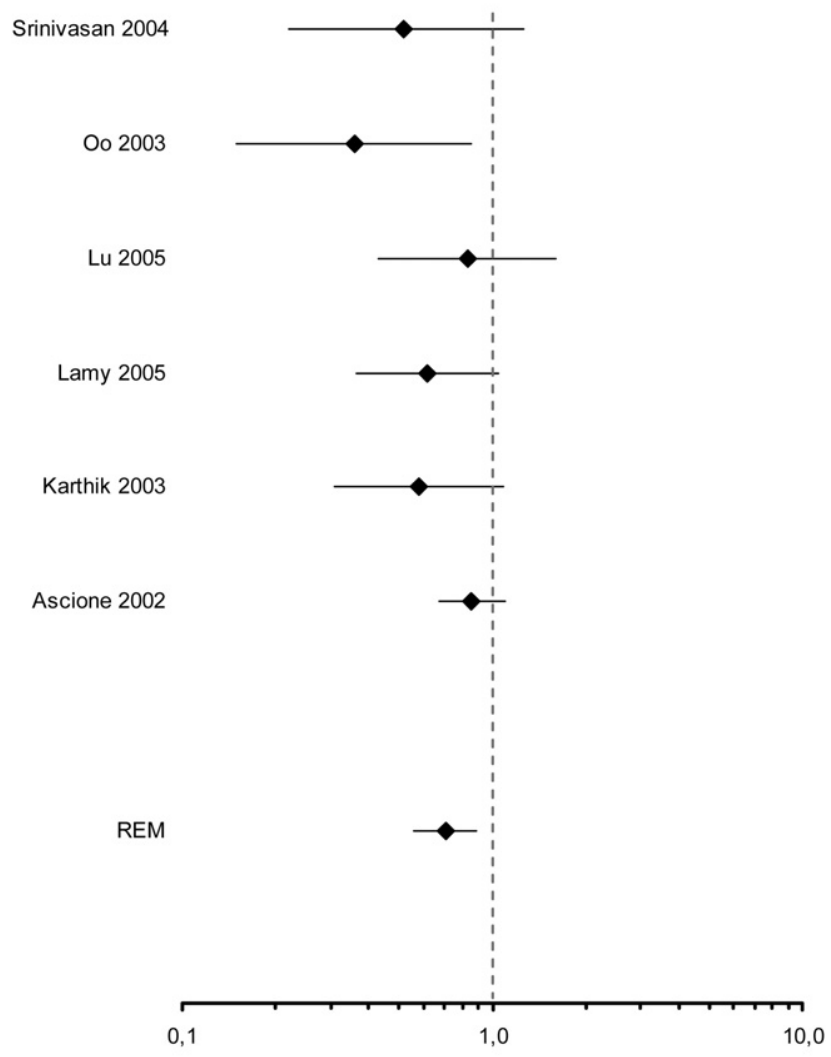

Odds Ratio (with 95\%-Cl)

FIGURE E1. Continued 
Mortality

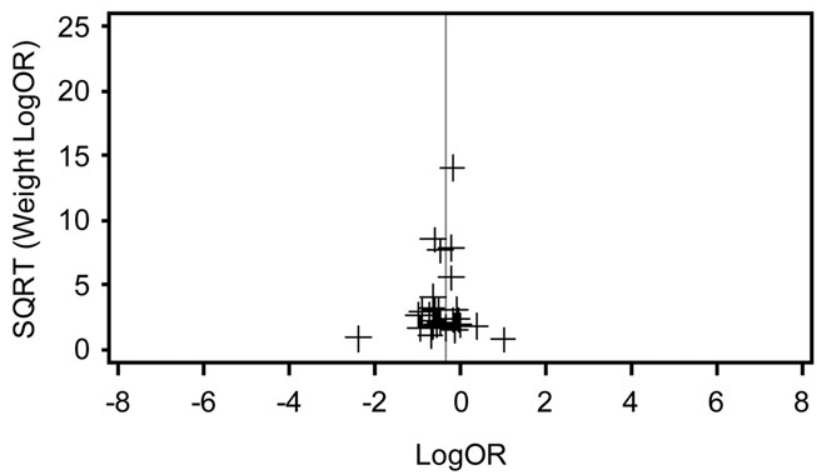

Myocardial infarction

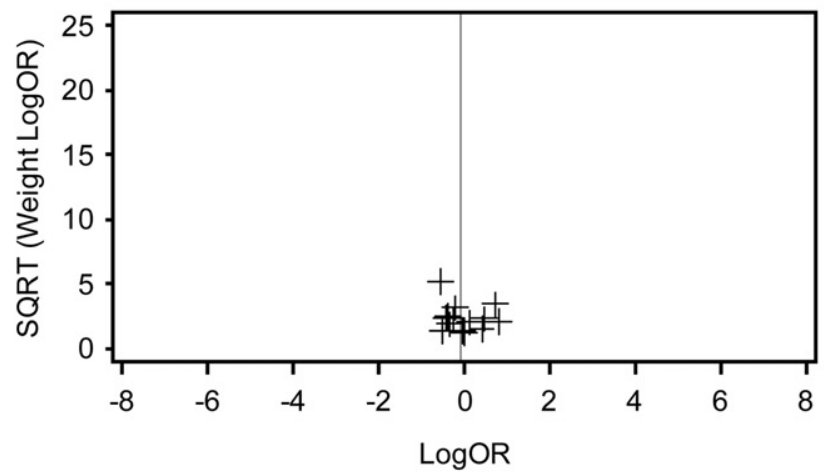

Stroke

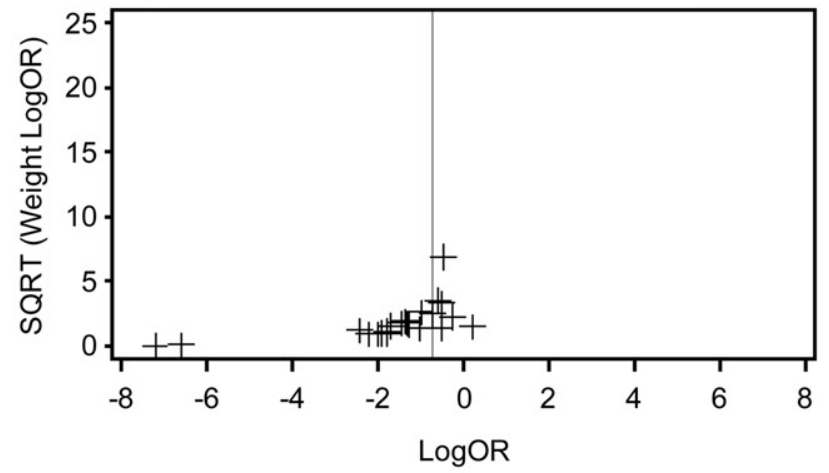

Atrial fibrillation

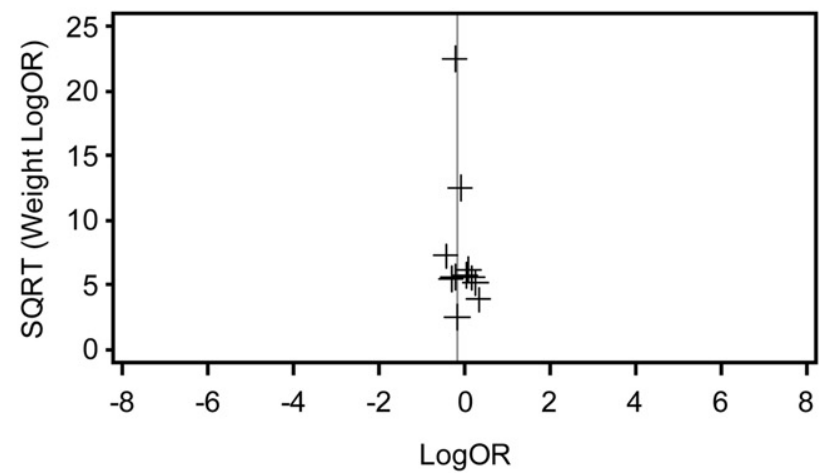

FIGURE E2. Funnel plots for all outcomes. SQRT, Square root; $O R$, odds ratio; $I A B P$, intraaortic balloon pump. 
Renal failure

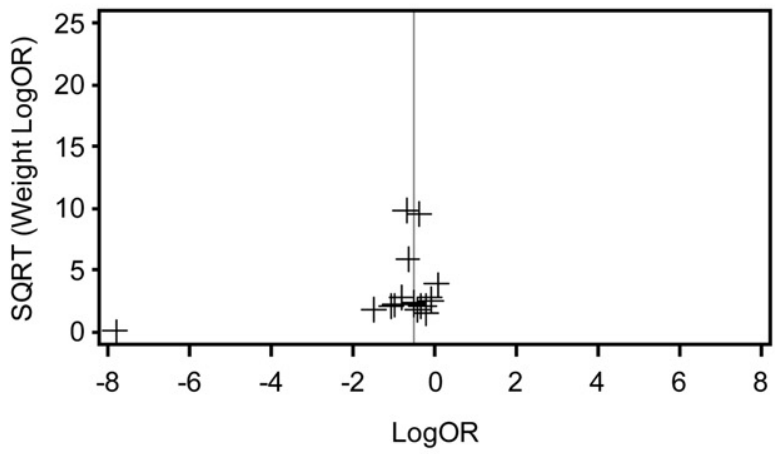

RBC transfusion

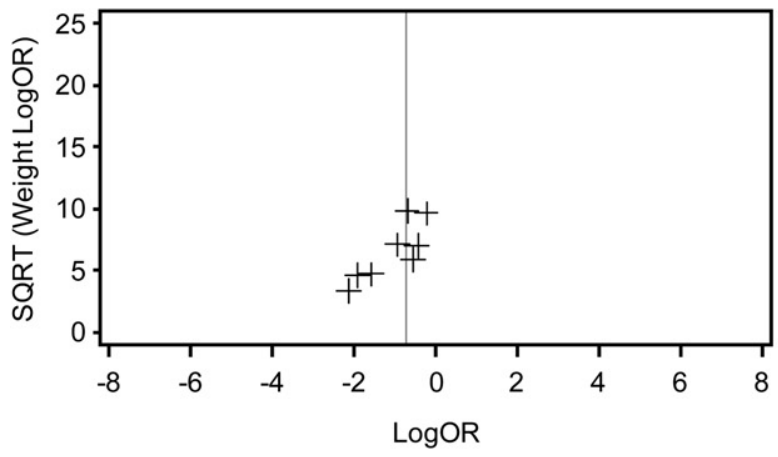

Re-operation for bleeding

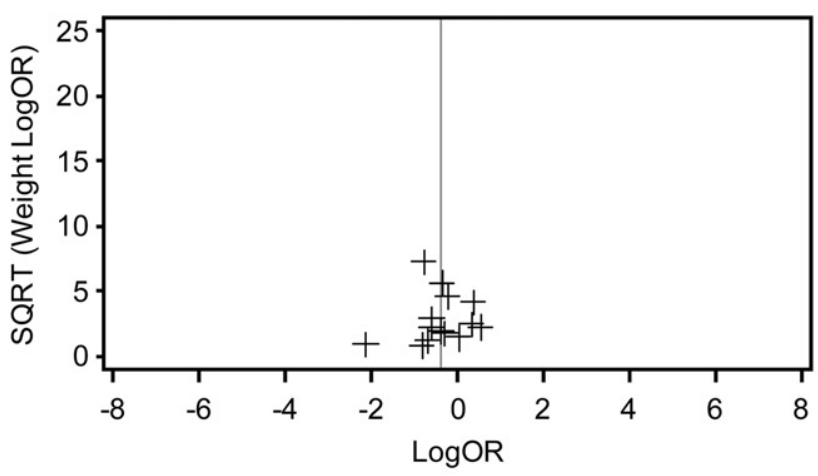

Prolonged ventilation

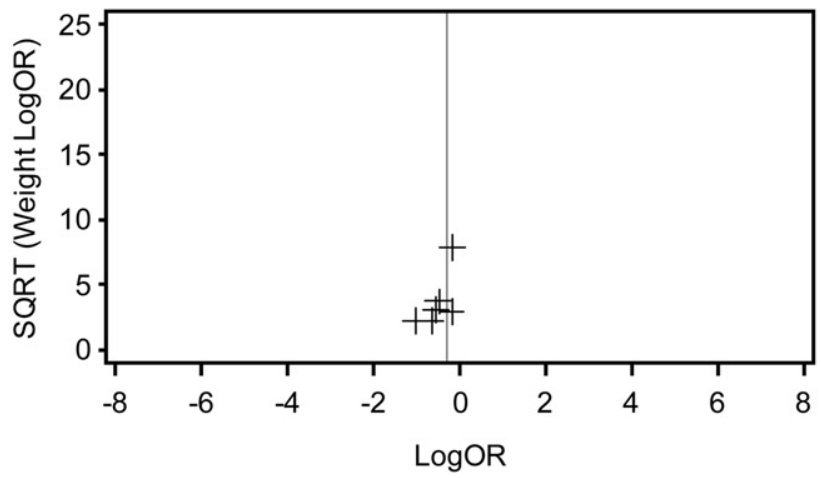

Inotropic support

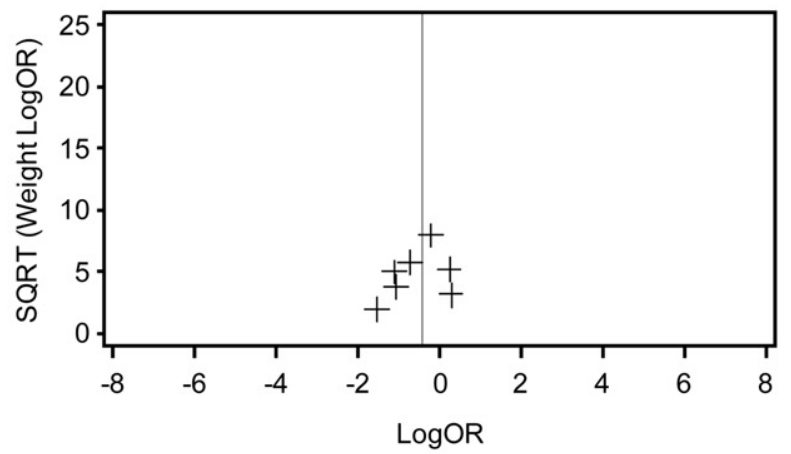

Wound infection

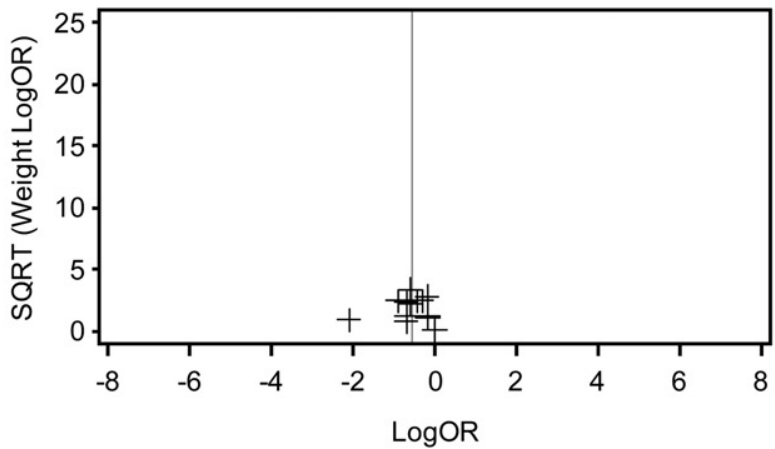

IABP support

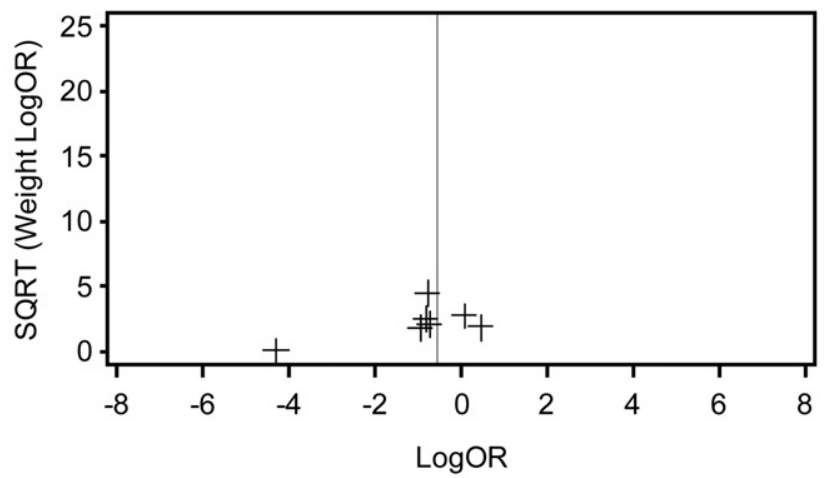

FIGURE E2. Continued 


\section{TABLE E1. List of included articles}

Ascione R, Reeves BC, Rees K, Angelini GD. Effectiveness of coronary artery bypass grafting with or without cardiopulmonary bypass in overweight patients. Circulation. 2002;106:1764-70.

Ascione R, Narayan P, Rogers CA, Lim KH, Capoun R, Angelini GD. Early and midterm clinical outcome in patients with severe left ventricular dysfunction undergoing coronary artery surgery. Ann Thorac Surg. 2003;76:793-9.

Boening A, Friedrich C, Hedderich J, Schoettler J, Fraund S, Cremer JT. Early and medium term results after on-pump and off-pump coronary artery surgery: a propensity score analysis. Ann Thorac Surg. 2003;76:2000-6.

Calafiore AM, Di Mauro M, Canosa C, Di Giammarco G, Iaco AL, Contini M. Myocardial revascularization with and without cardiopulmonary bypass: advantages, disadvantages and similarities. Eur J Cardiothorac Surg. 2003;24:953-60. [Calafiore 2003a]

Calafiore AM, Di Mauro M, Canosa C, Di Giammarco G, Iaco AL, Contini M. Early and late outcome of myocardial revascularization with and without cardiopulmonary bypass in high risk patients (EuroSCORE > or = 6). Eur J Cardiothorac Surg. 2003;23:360-7. [Calafiore 2003b]

Calafiore AM, Di Giammarco G, Teodori G, Iaco AL, Pano M, Contini M, et al. Bilateral internal thoracic artery grafting with and without cardiopulmonary bypass: six-year clinical outcome. J Thorac Cardiovasc Surg. 2005;130:340-5.

Chukwuemeka A, Weisel A, Maganti M, Nette AF, Wijeysundera DN, Beattie WS, et al. Renal dysfunction in high-risk patients after on-pump and off-pump coronary artery bypass surgery: a propensity score analysis. Ann Thorac Surg. 2005;80:2148-53.

Frankel TL, Stamou SC, Lowery RC, Kapetanakis EI, Hill PC, Haile E, et al. Risk factors for hemorrhage-related reexploration and blood transfusion after conventional versus coronary revascularization without cardiopulmonary bypass. Eur J Cardiothorac Surg. 2005;27:494-500.

Grunkemeier GL, Payne N, Jin R, Handy JR Jr. Propensity score analysis of stroke after off pump coronary artery bypass grafting. Ann Thorac Surg. 2002;74:301-5.

Ivanov J, Borger MA, Rao V, Cusimano RJ, David TE. Propensity score, pairmatched study of early hospital outcomes for off-pump versus on-pump coronary artery bypass. Unpublished Abstract, CCC 2004 (Canadian Cardiological Congress) 2006. Available at: http://www.pulsus.com/ccc2004/abs/a233.htm. Accessed January 10, 2010.

Karthik S, Musleh G, Grayson AD, Keenan DJ, Hasan R, Pullan DM, et al. Effect of avoiding cardiopulmonary bypass in non-elective coronary artery bypass surgery: a propensity score analysis. Eur J Cardiothorac Surg. 2003;24:66-71.

Karthik S, Musleh G, Grayson AD, Keenan DJ, Pullan DM, Dihmis WC, et al. Coronary surgery in patients with peripheral vascular disease: effect of avoiding cardiopulmonary bypass. Ann Thorac Surg. 2004;77:1245-9.

Lamy A, Farrokhyar F, Kent R, Wang X, Smith KM, Mullen JC, et al. The Canadian off-pump coronary artery bypass graft registry: a one-year prospective comparison with on-pump coronary artery bypass grafting. Can J Cardiol. 2005;21:1175-81.

Lee AL, Fox SA, Stitt L, Abukhudair W, Benmusa A, Chu M, et al. Off pump versus on pump coronary bypass impact of selection bias on outcomes: matched group and selected group analysis. Unpublished Abstract, CCC 2004 (Canadian Cardiological Congress) 2006. Available at: http://www.pulsus.com/ ccc2004/abs/a235.htm. Accessed January 10, 2010.

Lu JC, Grayson AD, Pullan DM. On-pump versus off-pump surgical revascularization for left main stem stenosis: risk adjusted outcomes. Ann Thorac Surg. 2005;80:136-42.

Mack MJ, Pfister A, Bachand D, Emery R, Magee MJ, Connolly M, et al. Comparison of coronary bypass surgery with and without cardiopulmonary bypass in patients with multivessel disease. J Thorac Cardiovasc Surg. 2004;127:167-73. [Mack 2004a]

Mack MJ, Brown P, Houser F, Katz M, Kugelmass A, Simon A, et al. On-pump versus off-pump coronary artery bypass surgery in a matched sample of women: a comparison of outcomes. Circulation. 2004;110(11 Suppl 1):II1-6. [Mack 2004b]

Magee MJ, Jablonski KA, Stamou SC, Pfister AJ, Dewey TM, Dullum MK, et al. Elimination of cardiopulmonary bypass improves early survival for multivessel coronary artery bypass patients. Ann Thorac Surg. 2002;73:1196-202.

Magee MJ, Coombs LP, Peterson ED, Mack MJ. Patient selection and current practice strategy for off-pump coronary artery bypass surgery. Circulation. 2003;108 (Suppl 1):II9-14.

Meco M, Caratti A, Khlat B, Marotta A, Meco M, Babbini M, et al. Aortocoronary bypass grafting in patients over 75 years. Propensity score analysis of on versus off-pump, early and midterm results. Interact Cardiovasc Thorac Surg. 2004;3(Suppl 1):1-106.

Oo AY, Grayson AD, Patel NC, Pullan DM, Dihmis WC, Fabri BM. Is off-pump coronary surgery justified in EuroSCORE high-risk cases? A propensity score analysis. Interact Cardiovasc Thorac Surg. 2003;2:660-4.

Pandey R, Grayson AD, Pullan DM, Fabri BM, Dihmis WC. Total arterial revascularisation: effect of avoiding cardiopulmonary bypass on in-hospital mortality and morbidity in a propensity-matched cohort. Eur J Cardiothorac Surg. 2005;27:94-8.

Patel NC, Deodhar AP, Grayson AD, Pullan DM, Keenan DJ, Hasan R, et al. Neurological outcomes in coronary surgery: independent effect of avoiding cardiopulmonary bypass. Ann Thorac Surg. 2002;74:400-5. [Patel 2004a]

Patel NC, Grayson AD, Jackson M, Au J, Yonan N, Hasan R, et al. The effect off-pump coronary artery bypass surgery on in-hospital mortality and morbidity. Eur J Cardiothorac Surg. 2002;22:255-60. [Patel 2004b]

Sabik JF, Gillinov AM, Blackstone EH, Vacha C, Houghtaling PL, Navia J, et al. Does off-pump coronary surgery reduce morbidity and mortality? J Thorac Cardiovasc Surg. 2002;124:698-707.

Saunders PC, Grossi EA, Schwartz CF, Applebaum RM, Ribakove GH, Culliford AT, et al. Revascularization alone for functional mitral regurgitation: a propensity case-match analysis of the off pump coronary artery bypass approach. $J$ Am Coll Cardiol. 2004;43(Suppl 1):A274.

Seif JS, Zacky SS, Li L, Leventhal M, Bashour AC. A propensity matched comparison of cardiac and non-cardiac thoracic surgery patients on the incidence of new onset postoperative atrial arrhythmias. Anesthesiology. 2005;103:A345. 
Table E1. Continued

Sharony R, Grossi EA, Saunders PC, Galloway AC, Applebaum R, Ribakove GH, et al. Propensity case-matched analysis of off-pump coronary artery bypass grafting in patients with atheromatous aortic disease. J Thorac Cardiovasc Surg. 2004;127:406-13.

Srinivasan AK, Grayson AD, Fabri BM. On-pump versus off-pump coronary artery bypass grafting in diabetic patients: a propensity score analysis. Ann Thorac Surg. 2004;78:1604-9.

Stamou SC, Jablonski KA, Pfister AJ, Hill PC, Dullum MK, Bafi AS, et al. Stroke after conventional versus minimally invasive coronary artery bypass. Ann Thorac Surg. 2002;74:394-9.

Stamou SC, Jablonski KA, Garcia JM, Boyce SW, Bafi AS, Corso PJ. Operative mortality after conventional versus coronary revascularization without cardiopulmonary bypass. Eur J Cardiothorac Surg. 2004;26:549-53.

Stamou SC, Jablonski KA, Hill PC, Bafi AS, Boyce SW, Corso PJ. Coronary revascularization without cardiopulmonary bypass versus the conventional approach in high-risk patients. Ann Thorac Surg. 2005;79:552-7.

Stamou SC, Hill PC, Haile E, Prince S, Mack MJ, Corso PJ. Clinical outcomes of nonelective coronary revascularization with and without cardiopulmonary bypass. J Thorac Cardiovasc Surg. 2006;131:28-33.

Weerasinghe A, Athanasiou T, Al Ruzzeh S, Casula R, Tekkis PP, Amrani M, et al. Functional renal outcome in on-pump and off-pump coronary revascularization: a propensity-based analysis. Ann Thorac Surg. 2005;79:1577-83.

Williams ML, Muhlbaier LH, Schroder JN, Hata JA, Peterson ED, Smith PK, et al. Risk-adjusted short- and long-term outcomes for on-pump versus off-pump coronary artery bypass surgery. Circulation. 2005;112(9 Suppl):I366-70. 
TABLE E2. Results from the single studies

\begin{tabular}{|c|c|c|c|}
\hline \multicolumn{4}{|c|}{ Mortality } \\
\hline Study & OR $(95 \%$ CI $)$ & $\begin{array}{c}\text { Relative } \\
\text { weight }(\%) \text {, } \\
\text { RE } \\
\end{array}$ & $\begin{array}{c}\text { Relative } \\
\text { weight }(\%) \text {, } \\
\text { FE } \\
\end{array}$ \\
\hline Ascione 2002 & $0.37(0.18-0.77)$ & 2.29 & 1.32 \\
\hline Ascione 2003 & $1.45(0.51-4.17)$ & 1.15 & 0.63 \\
\hline Boening 2003 & $2.74(0.24-30.9)$ & 0.23 & 0.12 \\
\hline Calafiore 2003a & $0.41(0.21-0.79)$ & 2.77 & 1.63 \\
\hline Calafiore $2003 b$ & $0.52(0.28-0.96)$ & 3.04 & 1.82 \\
\hline Calafiore 2005 & $0.63(0.24-1.64)$ & 1.38 & 0.77 \\
\hline $\begin{array}{l}\text { Chukwuemeka } \\
2005\end{array}$ & $0.90(0.24-3.31)$ & 0.76 & 0.41 \\
\hline Ivanov 2006 & $0.71(0.22-2.26)$ & 0.96 & 0.52 \\
\hline Karthik 2003 & $0.83(0.36-1.93)$ & 1.76 & 0.99 \\
\hline Karthik 2004 & $0.98(0.35-2.75)$ & 1.20 & 0.66 \\
\hline Lamy 2005 & $0.90(0.48-1.69)$ & 2.96 & 1.76 \\
\hline Lu 2005 & $0.95(0.41-2.18)$ & 1.77 & 1.00 \\
\hline Mack 2004a & $0.54(0.43-0.68)$ & 12.35 & 13.25 \\
\hline Mack 2004b & $0.81(0.63-1.04)$ & 11.39 & 11.29 \\
\hline Magee 2002 & $0.53(0.32-0.83)$ & 4.73 & 3.07 \\
\hline Magee 2003 & $0.83(0.72-0.96)$ & 17.83 & 35.88 \\
\hline Meco 2004 & $0.09(0.01-0.83)$ & 0.28 & 0.15 \\
\hline Oo 2003 & $0.57(0.21-1.56)$ & 1.26 & 0.69 \\
\hline Pandey 2005 & $0.39(0.12-1.27)$ & 0.94 & 0.51 \\
\hline Patel 2002b & $0.59(0.31-1.12)$ & 2.86 & 1.69 \\
\hline Sabik 2002 & $0.50(0.09-2.73)$ & 0.45 & 0.24 \\
\hline Saunders 2006 & $0.87(0.30-2.47)$ & 1.16 & 0.64 \\
\hline Sharony 2004 & $0.54(0.29-1.03)$ & 2.86 & 1.70 \\
\hline Srinivasan 2004 & $0.53(0.18-1.55)$ & 1.10 & 0.60 \\
\hline Stamou 2004 & $0.63(0.50-0.83)$ & 11.08 & 10.72 \\
\hline Stamou 2005 & $0.48(0.23-0.98)$ & 2.29 & 1.32 \\
\hline Stamou 2006 & $0.81(0.57-1.15)$ & 7.48 & 5.67 \\
\hline Williams 2005 & $0.53(0.22-1.24)$ & 1.66 & 0.93 \\
\hline \multicolumn{4}{|c|}{ Stroke } \\
\hline Study & OR $(95 \% \mathrm{CI})$ & $\begin{array}{c}\text { Relative } \\
\text { weight }(\%) \text {, } \\
\text { RE }\end{array}$ & $\begin{array}{c}\text { Relative } \\
\text { weight }(\%) \text {, } \\
\text { FE }\end{array}$ \\
\hline Calafiore 2003a & $0.26(0.09-0.80)$ & 4.21 & 2.68 \\
\hline Calafiore $2003 b$ & $0.18(0.05-0.63)$ & 3.48 & 2.14 \\
\hline Calafiore 2005 & $1.25(0.33-4.69)$ & 3.12 & 1.89 \\
\hline $\begin{array}{l}\text { Chukwuemeka } \\
2005\end{array}$ & $0.00(0.00->100)$ & 0.00 & 0.00 \\
\hline $\begin{array}{l}\text { Grunkemeier } \\
2002\end{array}$ & $0.37(0.17-0.77)$ & 7.64 & 5.86 \\
\hline Ivanov 2006 & $0.11(0.01-0.87)$ & 1.37 & 0.77 \\
\hline Karthik 2003 & $0.36(0.08-1.53)$ & 2.56 & 1.51 \\
\hline Karthik 2004 & $0.09(0.02-0.50)$ & 2.19 & 1.27 \\
\hline Lamy 2005 & $0.49(0.23-1.06)$ & 7.43 & 5.63 \\
\hline Lee 2006 & $0.14(0.02-1.13)$ & 1.33 & 0.74 \\
\hline Lu 2005 & $0.17(0.02-1.31)$ & 1.35 & 0.75 \\
\hline Mack 2004a & $0.64(0.48-0.85)$ & 18.56 & 40.44 \\
\hline Oo 2003 & $0.17(0.03-0.93)$ & 1.94 & 1.11 \\
\hline Pandey 2005 & $0.00(0.00->100)$ & 0.00 & 0.00 \\
\hline Patel 2002a & $0.24(0.08-0.74)$ & 4.16 & 2.64 \\
\hline
\end{tabular}

Table E2. Continued

\begin{tabular}{lccc}
\hline \multicolumn{4}{c}{ Stroke } \\
\hline \multicolumn{1}{c}{ Study } & OR (95\% CI) & $\begin{array}{c}\text { Relative } \\
\text { weight } \mathbf{\%}), \\
\text { RE }\end{array}$ & $\begin{array}{c}\text { Relative } \\
\text { weight }(\%), \\
\text { FE }\end{array}$ \\
\hline Patel 2002b & $0.26(0.09-0.70)$ & 4.77 & 3.12 \\
Sabik 2002 & $0.60(0.14-2.51)$ & 2.68 & 1.59 \\
Sharony 2004 & $0.27(0.09-0.84)$ & 4.09 & 2.59 \\
Srinivasan 2004 & $0.15(0.02-0.96)$ & 1.56 & 0.88 \\
Stamou 2002 & $0.56(0.33-1.00)$ & 11.09 & 10.69 \\
Stamou 2006 & $0.60(0.33-1.08)$ & 10.28 & 9.35 \\
Williams 2005 & $0.78(0.33-1.87)$ & 6.19 & 4.37
\end{tabular}

Myocardial infarction

\begin{tabular}{|c|c|c|c|}
\hline Study & OR $(95 \%$ CI $)$ & $\begin{array}{c}\text { Relative } \\
\text { weight }(\%) \text {, } \\
\text { RE }\end{array}$ & $\begin{array}{c}\text { Relative } \\
\text { weight }(\%) \text {, } \\
\text { FE }\end{array}$ \\
\hline Ascione 2002 & $2.29(0.91-5.76)$ & 6.59 & 4.86 \\
\hline Ascione 2003 & $1.61(0.71-3.85)$ & 7.38 & 5.79 \\
\hline Boening 2003 & $1.01(0.22-4.66)$ & 3.05 & 1.77 \\
\hline Calafiore 2003a & $0.66(0.30-1.48)$ & 7.83 & 6.39 \\
\hline Calafiore 2003b & $0.76(0.33-1.76)$ & 7.51 & 5.96 \\
\hline Calafiore 2005 & $1.51(0.42-5.36) 4.14$ & 2.57 & \\
\hline $\begin{array}{l}\text { Chukwuemeka } \\
2005\end{array}$ & $1.13(0.43-2.94)$ & 6.27 & 4.52 \\
\hline Karthik 2003 & $0.72(0.26-1.98)$ & 5.79 & 4.02 \\
\hline Karthik 2004 & $0.96(0.24-3.92)$ & 3.55 & 2.12 \\
\hline Lamy 2005 & $2.09(1.18-3.69)$ & 11.18 & 12.74 \\
\hline Mack 2004a & $0.58(0.40-0.85)$ & 14.80 & 29.60 \\
\hline Patel 2002b & $0.81(0.44-1.51)$ & 10.42 & 10.89 \\
\hline Sabik 2002 & $0.60(0.14-2.51)$ & 3.38 & 2.00 \\
\hline Srinivasan 2004 & $0.68(0.31-1.48)$ & 8.11 & 6.78 \\
\hline
\end{tabular}

\begin{tabular}{lccc}
\hline \multicolumn{1}{c}{ Study } & OR (95\% CI) & $\begin{array}{c}\text { Relative } \\
\text { weight }(\%), \\
\text { RE }\end{array}$ & $\begin{array}{c}\text { Relative } \\
\text { weight }(\%), \\
\text { FE }\end{array}$ \\
\hline Ascione 2002 & $0.73(0.51-1.04)$ & 7.95 & 3.25 \\
Ascione 2003 & $0.85(0.39-1.87)$ & 2.45 & 0.67 \\
Calafiore 2003a & $0.64(0.49-0.84)$ & 10.61 & 5.70 \\
Calafiore 2003b & $0.79(0.56-1.12)$ & 8.25 & 3.47 \\
Karthik 2003 & $1.30(0.89-1.88)$ & 7.51 & 2.95 \\
Karthik 2004 & $1.39(0.84-2.30)$ & 5.03 & 1.63 \\
Lu 2005 & $1.11(0.81-1.53)$ & 9.03 & 4.08 \\
Mack 2004a & $0.79(0.73-0.87)$ & 17.64 & 54.44 \\
Pandey 2005 & $1.03(0.73-1.45)$ & 8.43 & 3.60 \\
Seif 2005 & $0.91(0.78-1.07)$ & 15.05 & 16.89 \\
Srinivasan 2004 & $1.21(0.85-1.72)$ & 8.06 & 3.32
\end{tabular}

Renal failure

\begin{tabular}{lccc}
\hline \multicolumn{1}{c}{ Study } & OR (95\% CI) & $\begin{array}{c}\text { Relative } \\
\text { weight }(\%), \\
\text { RE }\end{array}$ & $\begin{array}{c}\text { Relative } \\
\text { weight }(\%), \\
\text { FE }\end{array}$ \\
\hline Ascione 2002 & $0.90(0.44-1.85)$ & 4.20 & 2.50 \\
Ascione 2003 & $0.70(0.28-1.79)$ & 2.64 & 1.50 \\
Calafiore 2003a & $0.80(0.31-2.03)$ & 2.61 & 1.48 \\
\hline
\end{tabular}

(Continued) 
Table E2. Continued

\begin{tabular}{llcc}
\hline \multicolumn{4}{c}{ Renal failure } \\
\hline \multicolumn{1}{c}{ Study } & OR (95\% CI) & $\begin{array}{c}\text { Relative } \\
\text { weight }(\%),\end{array}$ & $\begin{array}{c}\text { Relative } \\
\text { weight }(\%)\end{array}$ \\
\hline Chukwuemeka & $0.81(0.22-2.96)$ & 1.42 & FE \\
$\quad$ 2005 & & & 0.77 \\
Karthik 2003 & $0.44(0.22-0.90)$ & 4.34 & \\
Karthik 2004 & $0.59(0.26-1.34)$ & 3.31 & 2.60 \\
Lamy 2005 & $0.23(0.08-0.69)$ & 2.00 & 1.92 \\
Lu 2005 & $0.92(0.42-1.98)$ & 3.66 & 1.11 \\
Mack 2004a & $0.50(0.41-0.61)$ & 22.42 & 2.14 \\
Mack 2004b & $1.07(0.64-1.78)$ & 7.48 & 32.79 \\
Oo 2003 & $0.35(0.14-0.89)$ & 2.66 & 4.99 \\
Pandey 2005 & $0.61(0.25-1.48)$ & 2.83 & 1.51 \\
Sabik 2002 & $0.00(0.00->100)$ & 0.00 & 1.62 \\
Sharony 2004 & $0.66(0.23-1.88)$ & 2.10 & 0.00 \\
Srinivasan 2004 & $0.38(0.16-0.94)$ & 2.88 & 1.17 \\
Stamou 2006 & $0.52(0.37-0.72)$ & 13.57 & 1.64 \\
Weerasinghe & $0.69(0.56-0.85)$ & 21.87 & 11.63 \\
$\quad$ 2005 & & & 30.64
\end{tabular}

Inotropic support

\begin{tabular}{lccc}
\hline \multicolumn{1}{c}{ Study } & OR (95\% CI) & $\begin{array}{c}\text { Relative } \\
\text { weight }(\%), \\
\text { RE }\end{array}$ & $\begin{array}{c}\text { Relative } \\
\text { weight }(\%), \\
\text { FE }\end{array}$ \\
\hline Ascione 2002 & $0.81(0.63-1.03)$ & 16.71 & 35.80 \\
Ascione 2003 & $0.22(0.08-0.56)$ & 9.33 & 2.29 \\
Boening 2003 & $1.33(0.71-2.47)$ & 12.92 & 5.57 \\
Chukwuemeka & $1.27(0.87-1.85)$ & 15.59 & 15.35 \\
$\quad$ 2005 & & & \\
Lu 2005 & $0.49(0.35-0.69)$ & 15.93 & 18.78 \\
Oo 2003 & $0.35(0.21-0.59)$ & 14.11 & 8.11 \\
Pandey 2005 & $0.33(0.23-0.49)$ & 15.42 & 14.10 \\
& & & \\
& \multicolumn{2}{c}{ RBC transfusion } \\
\hline
\end{tabular}

\begin{tabular}{llcr}
\hline \multicolumn{1}{c}{ Study } & OR (95\% CI) & $\begin{array}{c}\text { Relative } \\
\text { weight }(\%), \\
\text { RE }\end{array}$ & $\begin{array}{c}\text { Relative } \\
\text { weight }(\%), \\
\text { FE }\end{array}$ \\
\hline Ascione 2002 & $0.40(0.30-0.52)$ & 12.98 & 13.27 \\
Calafiore 2003b & $0.59(0.42-0.81)$ & 12.63 & 9.26 \\
Frankel 2005 & $0.50(0.39-0.58)$ & 13.38 & 25.49 \\
Oo 2003 & $0.12(0.07-0.22)$ & 10.72 & 3.06 \\
Pandey 2005 & $0.15(0.10-0.23)$ & 11.93 & 5.56 \\
Sabik 2002 & $0.64(0.48-0.84)$ & 12.97 & 13.05 \\
Srinivasan 2004 & $0.21(0.14-0.32)$ & 12.02 & 5.88 \\
Williams 2005 & $0.80(0.66-0.99)$ & 13.36 & 24.42 \\
& \multicolumn{3}{c}{ Wound infection } \\
\hline
\end{tabular}

\begin{tabular}{lccc}
\hline Study & OR $(\mathbf{9 5 \%}$ CI) & $\begin{array}{c}\text { Relative } \\
\text { weight }(\%), \\
\text { RE }\end{array}$ & $\begin{array}{c}\text { Relative } \\
\text { weight }(\%), \\
\text { FE }\end{array}$ \\
\hline Ascione 2002 & $0.83(0.42-1.66)$ & 14.96 & 14.96 \\
Ascione 2003 & $0.84(0.16-4.55)$ & 2.52 & 2.52 \\
Boening 2003 & $1.00(0.00->100)$ & 0.01 & 0.01 \\
\hline
\end{tabular}

Table E2. Continued

\begin{tabular}{|c|c|c|c|}
\hline \multicolumn{4}{|c|}{ Wound infection } \\
\hline Study & OR $(95 \% \mathrm{CI})$ & $\begin{array}{c}\text { Relative } \\
\text { weight }(\%) \text {, } \\
\text { RE }\end{array}$ & $\begin{array}{c}\text { Relative } \\
\text { weight }(\%) \text {, } \\
\text { FE }\end{array}$ \\
\hline $\begin{array}{l}\text { Chukwuemeka } \\
2005\end{array}$ & $0.86(0.18-4.16)$ & 2.82 & 2.82 \\
\hline Karthik 2004 & $0.50(0.11-2.33)$ & 3.03 & 3.03 \\
\hline Lu 2005 & $0.73(0.33-1.61)$ & 11.25 & 11.25 \\
\hline Mack 2004a & $0.54(0.31-0.97)$ & 21.33 & 21.33 \\
\hline Mack 2004b & $0.50(0.21-1.17)$ & 9.78 & 9.78 \\
\hline Pandey 2005 & $0.41(0.19-0.92)$ & 11.17 & 11.17 \\
\hline Sabik 2002 & $0.12(0.02-0.99)$ & 1.63 & 1.63 \\
\hline Sharony 2004 & $0.50(0.04-5.53)$ & 1.22 & 1.22 \\
\hline Srinivasan 2004 & $0.65(0.29-1.42)$ & 11.20 & 11.20 \\
\hline Williams 2005 & $0.56(0.23-1.34)$ & 9.10 & 9.10 \\
\hline \multicolumn{4}{|c|}{ Reoperation for bleeding } \\
\hline Study & OR $(95 \% \mathrm{CI})$ & $\begin{array}{c}\text { Relative } \\
\text { weight }(\%) \text {, } \\
\text { RE } \\
\end{array}$ & $\begin{array}{c}\text { Relative } \\
\text { weight }(\%) \text {, } \\
\text { FE } \\
\end{array}$ \\
\hline Ascione 2002 & $0.56(0.28-1.10)$ & 8.50 & 5.12 \\
\hline Ascione 2003 & $0.50(0.10-2.50)$ & 2.66 & 0.92 \\
\hline Boening 2003 & $0.44(0.04-4.33)$ & 1.44 & 0.46 \\
\hline Frankel 2005 & $0.80(0.53-1.24)$ & 12.10 & 13.26 \\
\hline Karthik 2003 & $1.72(0.73-4.04)$ & 6.68 & 3.27 \\
\hline Karthik 2004 & $1.03(0.27-3.95)$ & 3.58 & 1.33 \\
\hline Lu 2005 & $1.39(0.63-3.07)$ & 7.30 & 3.82 \\
\hline Mack 2004a & $0.46(0.35-0.60)$ & 14.39 & 32.94 \\
\hline Pandey 2005 & $0.56(0.23-1.36)$ & 6.45 & 3.08 \\
\hline Patel 2002b & $1.45(0.90-2.31)$ & 11.41 & 10.78 \\
\hline Sabik 2002 & $0.69(0.26-1.84)$ & 5.67 & 2.52 \\
\hline Sharony 2004 & $0.12(0.02-0.98)$ & 1.69 & 0.55 \\
\hline Srinivasan 2004 & $0.74(0.25-2.23)$ & 4.85 & 2.00 \\
\hline Stamou 2006 & $0.70(0.50-1.00)$ & 13.29 & 19.94 \\
\hline
\end{tabular}

IABP support

\begin{tabular}{lccc}
\hline \multicolumn{1}{c}{ Study } & OR (95\% CI) & $\begin{array}{c}\text { Relative } \\
\text { weight }(\boldsymbol{\%}), \\
\text { RE }\end{array}$ & $\begin{array}{c}\text { Relative } \\
\text { weight }(\%), \\
\text { FE }\end{array}$ \\
\hline Ascione 2002 & $0.39(0.14-1.15)$ & 10.73 & 7.49 \\
Ascione 2003 & $1.59(0.57-4.55)$ & 10.96 & 7.69 \\
Boening 2003 & $0.01(0.00->100)$ & 0.04 & 0.02 \\
Karthik 2003 & $0.44(0.21-0.96)$ & 17.03 & 14.37 \\
Lu 2005 & $1.07(0.52-2.18)$ & 18.33 & 16.16 \\
Oo 2003 & $0.48(0.19-1.23)$ & 12.85 & 9.52 \\
Stamou 2006 & $0.46(0.30-0.71)$ & 30.06 & 44.74 \\
& & & \\
& & Prolonged ventilation & \\
\hline \multicolumn{1}{c}{ Study } & OR (95\% CI) & Relative & Relative \\
& weight $(\boldsymbol{\%})$, & weight $(\boldsymbol{\%})$, \\
Ascione 2002 & $0.86(0.67-1.10)$ & 47.62 & FE \\
Karthik 2003 & $0.58(0.31-1.08)$ & 12.10 & 59.46 \\
Lamy 2005 & $0.61(0.36-1.04)$ & 16.24 & 9.38 \\
Lu 2005 & $0.83(0.43-1.61)$ & 10.94 & 13.18 \\
\hline
\end{tabular}

(Continued) 
Table E2. Continued

\begin{tabular}{|c|c|c|c|}
\hline \multicolumn{4}{|c|}{ Prolonged ventilation } \\
\hline Study & OR $(95 \%$ CI $)$ & $\begin{array}{c}\text { Relative } \\
\text { weight }(\%) \text {, } \\
\text { RE }\end{array}$ & $\begin{array}{c}\text { Relative } \\
\text { weight }(\%), \\
\text { FE }\end{array}$ \\
\hline Oo 2003 & $0.36(0.15-0.86)$ & 6.54 & 4.79 \\
\hline Srinivasan 2004 & $0.52(0.22-1.26)$ & 6.55 & 4.80 \\
\hline
\end{tabular}

